Universidad de Lima

Escuela de Posgrado

Maestría en Tributación y Política Fiscal

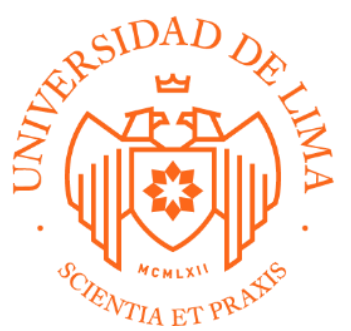

\title{
PROBLEMÁTICA DE LAS INVERSIONES EN LOS CONVENIOS DE ESTABILIDAD MINEROS Y LA NECESIDAD DEUNA MEJOR REGULACIÓN
}

Trabajo de investigación para optar el Grado Académico de Maestro en

Tributación y Política Fiscal

Yessela Victoria Escriba Marcelo

Código 20152599

Marco Arturo Coello Cáceres

Código 20001007

Asesores

David Wharton

Miguel Puga

Lima - Perú

Setiembre de 2019 
Dedico la presente tesis a mi hija Marissa, quien es mi mayor motivación para llegar a cumplir con todas mis metas.

Mi agradecimiento más sincero a mi compañera de tesis Yessela Escriba Marcelo, quien siempre fue perseverante en culminar con el presente trabajo y nunca perdió la fe." - Marco Coello 


\section{INDICE}

PROBLEMÁTICA DE LAS INVERSIONES EN LOS CONVENIOS DE ESTABILIDAD MINEROS Y LA NECESIDAD DE UNA MEJOR REGULACIÓN ......................................................1

INTRODUCCIÓN .......................................................................................6

CAPÍTULO I: LOS RECURSOS NATURALES Y SU APROVECHAMIENTO SOSTENIBLE A TRAVÉS DE

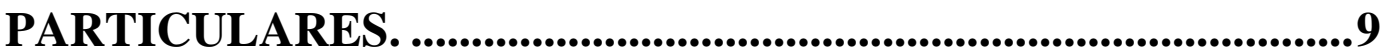

1.1.Los recursos naturales en la constitución. ................................9

1.1.1. De los deberes del Estado. .............................................

1.1.2. De los recursos naturales y su uso sostenible. ...................10

1.2. De la limitación de la potestad tributaria del Estado para la promoción de inversiones.

1.3.De la promoción de la inversión privada....................................17

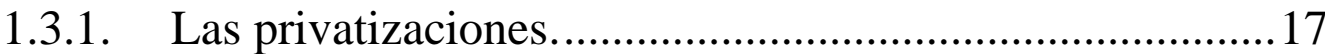

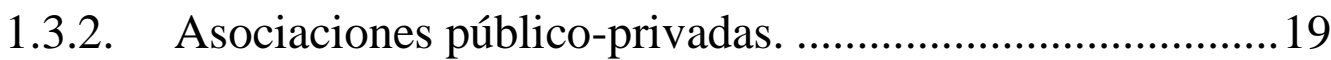

1.4.De las concesiones en el sector minero. ...................................20

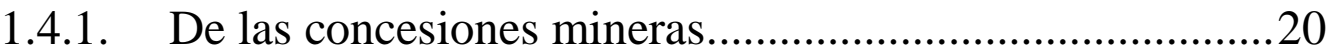

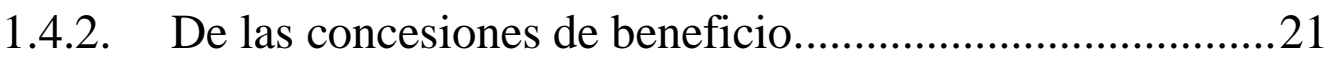

1.4.3. De las concesiones de labor general. ...............................22

1.4.4. De las concesiones de transporte minero..........................22

1.5.De los contratos del sector hidrocarburos...............................22

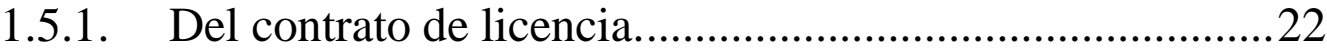

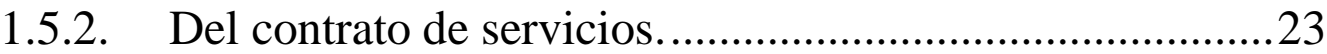




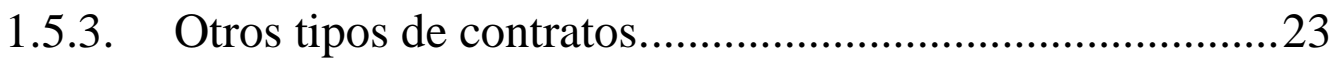

1.6. Conclusiones del presente capitulo............................................23

CAPÍTULO II: LOS CONVENIOS DE ESTABILIDAD EN

EL SECTOR MINERO_............................................................25

2.1.Importancia de sector minero en la economía peruana. ............25

2.2.Razones económicas para la celebración de Convenios de Estabilidad. .25

2.3.Cronología de los convenios de estabilidad en la legislación peruana. 27

2.4.Evolución de los Convenios de Estabilidad Tributaria en el TUO de la Ley General de Minería aprobado por Decreto Supremo 014-92EM y sus normas modificatorias. 32

2.4.1. Del texto original del TUO de la Ley General de Minería (Texto original) 32

2.4.2. Modificaciones realizadas por el Decreto Ley 26121 publicado el 30 de diciembre de 1992. 35

2.4.3. Modificaciones realizadas por la Ley 27341 publicada el 18 de agosto del 2000. 35

2.4.4. Modificaciones realizadas por la Ley 27343 publicada el 06 de septiembre del 2000. 35

2.4.5. Modificaciones realizadas por la Ley 27909 publicada el 08 de enero del 2003 36

2.5.Problemática en el sector minero con convenios de estabilidad. Problemática relacionada a la estabilidad de la inversión en las 
concesiones mineras, así como de las inversiones adicionales no previstas en el contrato de estabilidad. - Caso Cerro Verde....38

2.5.1. Hechos expuestos en la RTF $N^{\circ} 08252-1-2013 \ldots \ldots \ldots \ldots \ldots . . . .39$

3. CAPITULO III: PLANTEAMIENTOS PARA MEJORAR LA ESTABILIDAD DE LAS INVERSIONES EN EL SECTOR

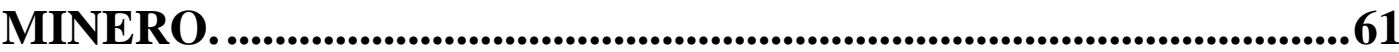

3.1.La confianza legitima y buena fe en la interpretación de la normatividad estabilizada.

3.2.Sobre la posibilidad de aplicar disposiciones de los Decretos Legislativos 662 y 774 y las normas tributarias del TUO de la Ley Orgánica de Hidrocarburos al sector minero.

3.2.1. De los beneficios del Decreto Legislativo 662 y 757 65

3.2.2. De las normas tributarias del TUO de la Ley Orgánica de Hidrocarburos .67

3.2.3. De nuestra opinión respecto de lo que podría aportar los Convenios de los Decretos Legislativos 662 y 757 y el TUO de la Ley Orgánica de Hidrocarburos al sector minero. 68

3.3.Del Proyecto de Ley $\mathrm{N}^{\circ}$ 3664/2018-PE para enmendar los problemas de los Convenios de estabilidad mineros .70

4. CAPÍTULO IV: CONCLUSIONES.....................................73

5. CAPÍTULO V: RECOMENDACIONES ...........................76

6. BIBLIOGRAFÍA ......................................................................80 


\section{INTRODUCCIÓN}

La minería desde hace muchas décadas nos ha brindado productos de exportación tradicional, habiendo sido estos reconocidos como tales en el ordenamiento jurídico conforme puede verificarse del Decreto Supremo $N^{\circ}$ 015-76-CO-CE de fecha 8 de junio de 1976 que aprobó la Lista de Productos de Exportación Tradicional, así como del Decreto Supremo N 76-92-EM promulgado el 01 de mayo de 1992, que actualiza dicha lista.

Asimismo, precisamos que la minería ha sido clave en el desarrollo nacional, teniendo un aporte considerable en el producto bruto interno (PBI), generando de esta manera mayores divisas, e ingresos fiscales por tributos, sin embargo, ello ha tenido como consecuencia, que seamos un país dependiente de la minería y que nos afecte todos los aspectos relacionados a ella, como la volatilidad de los precios de los minerales, el agotamiento de las reservas así como los problemas sociales y ambientales, pudiendo ello evidenciarse cuando comparamos el PBI total año por año respecto del PBI del sector minero e hidrocarburos, y vemos que guardan un correlato bastante marcado (Banco Central de Reserva del Perú, 2019), siendo visible que si se ve afectado el sector minero, ello va a repercutir en el PBI nacional total.

En el presente instrumento, buscaremos generar propuestas necesarias a efectos de analizar la regulación de los convenios de estabilidad celebrados por el sector minero con el objeto de identificar la problemática regulatoria que ha generado que desde el 2013 (Ministerio de Energía y Minas), no se haya celebrado ningún convenio nuevo en el sector minero y consideramos que ello se debe a diversos errores legislativos originados en la modificación del TUO de la Ley General de Minería, como ha ocurrido con las Leyes 30230 y 30296, que en lugar de atraer la inversión la han desincentivado, teniendo como consecuencia que solo existan siete convenios vigentes según el Ministerio de Economía y Finanzas, los cuales vencen entre el 2021 y 2030. 
Debido a lo antes mencionado, es importante replantear que mejoras se pueden realizar en el TUO de la Ley General de Minería, para aumentar la base tributaria, mejorar la recaudación, e incrementar las inversión privada para lograr un bienestar general, buscando siempre el equilibrio entre un pago de tributos justo con arreglo a la capacidad contributiva, con reglas claras que puedan contribuir a que el inversionista pueda prever lo que pagará en impuestos, pudiendo actuar en base a la buena fe y el principio de confianza legítima, sobre todo si se aplica la ley de acuerdo a los propios criterios que ha establecido la Administración Tributaria en sus informes y el Tribunal Fiscal en su jurisprudencia.

En concreto, el objeto de la presente tesis es analizar las controversias generadas en relación a los Convenios de Estabilidad en la industria minera. Analizar si es pertinente estabilizar en su totalidad las inversiones a realizarse en la concesión o las Unidades Económicas Administrativas (UEA) con estabilidad tributaria, quedando de esta manera incluidas las inversiones adicionales.

Como hipótesis de nuestro trabajo, hemos previsto que al régimen tributario minero se le pueden aplicar disposiciones similares al TUO de la Ley Orgánica de Hidrocarburos, donde hay mayor predictibilidad en lo que respecta a inversiones materia del contrato y las inversiones adicionales, las cuales se encuentran estabilizadas en el contrato de licencia respectivo.

El objetivo general de la presente tesis es contribuir a mejorar la regulación de los convenios de estabilidad mineros para las concesiones o UEA de las empresas mineras cuyas inversiones tienen uno o más convenios de estabilidad tributaria. Los objetivos específicos son los siguientes:

- Identificar las incongruencias normativas de los Convenios de Estabilidad en el TUO de la Ley General de Minería.

- Comparar los distintos marcos normativos establecidos en nuestro ordenamiento jurídico para regular los convenios de estabilidad, a efectos de comprobar si es factible incorporar disposiciones de otros tipos de convenios que ayuden a mejorar la ambigüedad y la interpretación del TUO de la Ley General de Minería.

- Determinar si se pueden corregir las deficiencias normativas de la Ley General de Minería encontrando un equilibrio entre el respeto de la capacidad contributiva del contribuyente y los intereses fiscales. 
- Desarrollar una propuesta normativa que reestructure la Ley General de Minería y el Reglamento de Garantías y Medidas de Promoción a la Inversión en la actividad minera - Decreto Supremo No 024-93-EM, respetando los parámetros establecidos en los Artículos $44^{\circ}, 66^{\circ}, 67^{\circ}, 62^{\circ}$ y $74^{\circ}$ de la Constitución Política del Estado, con la finalidad de promover el bienestar general, el aprovechamiento sostenible de los recursos naturales, otorgando garantías a la inversión y preservando la potestad tributaria del Estado.

Bajo estas premisas, hemos dividido el presente trabajo en cinco partes. En el primer capítulo de la presente tesis, se analizan las disposiciones constitucionales, respecto a los deberes del Estado, el respeto de éste sobre los convenios de estabilidad que suscribe con particulares, las disposiciones sobre la potestad tributaria del Estado y la administración de los recursos naturales y su aprovechamiento sostenible a través de particulares. Seguidamente, revisaremos las diversas formas de contratación del Estado con los particulares, respecto de los bienes de dominio público, para su aprovechamiento sostenible y la promoción del bienestar general.

En el segundo capítulo, analizaremos lo concerniente a los convenios de estabilidad, en específico los convenios de estabilidad del sector minero, la evolución de la estabilidad durante la vigencia del TUO de la Ley General de Minería, así como la problemática que existe en el sector referido y analizar porque no se han suscrito más convenios de estabilidad mineros desde el 27 de diciembre del 2013.

En la tercer capítulo, analizaremos los planteamientos que existen para mejorar la estabilidad de las inversiones en el sector minero, de modo que se pueda volver a atraer la inversión.

Finalmente, en los capítulos cuarto y quinto pondremos las conclusiones y recomendaciones de la presente tesis, en donde concluiremos una mejor estructura en forma y fondo para el TUO de la Ley General de Minería, de esa manera celebraremos más convenios de estabilidad y por ende, generamos más inversiones en beneficio del país. 


\section{CAPÍTULO I: Los recursos naturales y su aprovechamiento sostenible a través de particulares.}

\subsection{Los recursos naturales en la constitución.}

A efectos de iniciar la presente tesis y antes de adentrarnos a analizar la problemática en las inversiones en los Convenios de Estabilidad regulados por el TUO de la Ley General de Minería, hemos considerado pertinente partir de un análisis constitucional, y así hacer un breve análisis del Artículo $44^{\circ}$ de la Constitución Política del Estado vinculado a los deberes del estado, así como de los artículos $66^{\circ}$ y $67^{\circ}$ de la Constitución Política del Estado, sobre los recursos naturales y su uso sostenible. Los artículos antes mencionados, los consideramos prioritarios a efectos de poder determinar, cómo el Estado puede disponer el uso de los recursos naturales, para su aprovechamiento por particulares, y cuáles son sus responsabilidades frente a los inversionistas, así como a los ciudadanos.

A efectos de priorizar la importancia de los temas a tratar, empezaremos por los deberes del Estado, para pasar seguidamente a los recursos naturales y su uso sostenible.

\subsubsection{De los deberes del Estado.}

En el presente punto analizaremos cuales son las obligaciones que tiene el Estado frente a sus ciudadanos, lo cual es relevante para analizar el presente tema de tesis, ya que toda propuesta normativa tiene que estar dentro del orden constitucional; así que empezamos con el Artículo $44^{\circ}$ de la Constitución Política del Estado, sobre los deberes del estado, que señala lo siguiente:

“Artículo 44.- Son deberes primordiales del Estado: defender la soberanía nacional; garantizar la plena vigencia de los derechos humanos; proteger a la población de las amenazas contra su seguridad; y promover el bienestar general que se fundamenta en la justicia y en el desarrollo integral y equilibrado de la Nación. 
Asimismo, es deber del Estado establecer y ejecutar la política de fronteras y promover la integración, particularmente latinoamericana, así como el desarrollo y la cohesión de las zonas fronterizas, en concordancia con la política exterior.” (Constitución Política del Perú, 1993)

Este artículo, lo consideramos muy importante, ya que el Estado si bien puede promover la actividad minera por los particulares, dado a las obligaciones constitucionales que tiene frente a sus ciudadanos, se evidencia las razones del porque pide inversiones mínimas, y porque también porque regula las ampliaciones de dichas inversiones, y porque sobre todo celebra Convenios de Estabilidad limitando su potestad tributaria.

Una respuesta coherente, nos es brindada por el Tribunal Constitucional en su Sentencia 00048-2004-AI, que declaró infundada la demanda de inconstitucionalidad contra la Ley 28258 - Ley de Regalía Minera y sus modificatorias en cuyo fundamento 101 señala:

"El estatuto subjetivo constitucional del Estado -como personificación jurídica de la Administración-frente a los bienes domínales será el de un deber de garantía, protección y aprovechamiento del patrimonio de la Nación, consistente en asegurar la afectación íntegra de dichos bienes para promover el bienestar general que se fundamenta en la justicia y en el desarrollo integral y equilibrado de la Nación, de conformidad con el artículo $44^{\circ}$ de la Constitución."

Precisamos que la sentencia antes referida, interpreta en forma correcta el deber del estado de buscar el aprovechamiento del patrimonio de la Nación, para asegurar el bienestar general; es por eso que se considera coherente la aplicación de los Artículos $66^{\circ}, 67^{\circ}$ y $62^{\circ}$ en concordancia con el Artículo $74^{\circ}$ de la Constitución Política del Estado, cuya interpretación pasaremos a desarrollar.

\subsubsection{De los recursos naturales y su uso sostenible.}

Respecto a los recursos naturales, el Artículo $66^{\circ}$ de la Constitución señala: 
"Los recursos naturales, renovables y no renovables, son patrimonio de la Nación. El Estado es soberano en su aprovechamiento.

Por ley orgánica se fijan las condiciones de su utilización y de su otorgamiento a particulares" (Constitución Política del Perú, 1993).

El Artículo $67^{\circ}$ de la misma carta magna añade:

“Artículo 67.- El Estado determina la política nacional del ambiente. Promueve el uso sostenible de sus recursos naturales." (Constitución Política del Perú, 1993)

Por otro lado, la Ley Orgánica para el Aprovechamiento Sostenible de los Recursos Naturales - Ley $\mathrm{N}^{\circ} 26821$, norma el régimen de aprovechamiento sostenible de los recursos naturales, desarrollando los artículos $66^{\circ}$ y $67^{\circ}$ de la Constitución, y reconoce en su Artículo $3^{\circ}$ que los recursos naturales son "todo componente de la naturaleza, susceptible de ser aprovechado por el ser humano para la satisfacción de sus necesidades y que tenga un valor actual o potencial en el mercado." (Ley 26821, 1997), entre dichos recursos se incluyen el agua, el suelo, la diversidad biológica, la atmósfera y el espectro radioeléctrico, los minerales, entre otros.

El Artículo $19^{\circ}$ de la norma antes mencionada, es mucho más explícito que es el Estado quien otorga los derechos para el aprovechamiento de los recursos naturales a favor de los particulares mediante los mecanismos previstos en las leyes especiales, precisando que el Estado conserva el dominio, así como de los frutos, en tanto no se hayan concedido por algún título a los particulares. Dicho artículo se complementa con el Artículo $23^{\circ}$ de la misma norma, que señala que la concesión otorga a su titular el derecho de uso y disfrute del recurso natural concedido y, en consecuencia, la propiedad de los frutos y recursos a extraerse, otorgándoles a las concesiones la calidad de derechos reales, siendo bienes incorporales registrables. (Ley 26821, 1997)

Un aspecto de especial importancia respecto al manejo de los recursos naturales, es respecto a que el Tribunal Constitucional, ha hecho una interpretación sistemática del Artículo $66^{\circ}$ con el inciso 22) del Artículo $2^{\circ}$ de la Constitución, que reconoce el derecho fundamental de toda persona "a gozar de un ambiente equilibrado y adecuado al desarrollo de la vida" (Constitución Política del Perú, 1993). 
En la sentencia del Tribunal Constitucional $\mathrm{N}^{\circ}$ 01848-2011-AA, en su fundamento décimo señala que:

"El derecho a un ambiente equilibrado y adecuado comporta un deber negativo y positivo frente al Estado. Su dimensión negativa se traduce en la obligación del Estado de abstenerse de realizar cualquier tipo de actos que afecte al medio ambiente equilibrado y adecuado para el desarrollo de la vida y la salud humana. En su dimensión positiva le impone deberes y obligaciones destinadas a conservar el ambiente equilibrado, los cuales se traducen, a su vez, en un haz de posibilidades. Claro está que no solo supone tareas de conservación, sino también de prevención ante afectaciones a ese ambiente equilibrado.” (Sentencia del Tribunal Constitucional No 01848-2011-AA)

Ahora pasaremos a analizar como el Estado puede ceder los bienes que son patrimonio de la nación, así como los recursos naturales para su aprovechamiento sostenible en el sector privado, el cual debe priorizar el bienestar general a que se refiere el artículo $44^{\circ}$, siendo los diversos regímenes utilizados por el Estado los siguientes:

\subsection{De la limitación de la potestad tributaria del Estado para la promoción de inversiones.}

Consideramos pertinente antes de adentrarnos a los convenios, hacer un breve análisis constitucional de la estabilidad tributaria y su impacto en la potestad tributaria del estado, ya que podría cuestionarse su legitimidad, respecto a que, si ello constituye una renuncia del estado a su IUS IMPERIUM y si además ello, no constituiría un acto discriminatorio respecto a las personas naturales o jurídicas que no tienen convenios de estabilidad.

Para empezar, analizaremos el Artículo $62^{\circ}$ de la Constitución referido a la libertad de contratar y los contratos-ley, cuyo texto señala: 
"Artículo 62.- La libertad de contratar garantiza que las partes pueden pactar válidamente según las normas vigentes al tiempo del contrato. Los términos contractuales no pueden ser modificados por leyes u otras disposiciones de cualquier clase. Los conflictos derivados de la relación contractual sólo se solucionan en la vía arbitral o en la judicial, según los mecanismos de protección previstos en el contrato o contemplados en la ley.

Mediante contratos-ley, el Estado puede establecer garantías y otorgar seguridades. No pueden ser modificados legislativamente, sin perjuicio de la protección a que se refiere el párrafo precedente." (Constitución Política del Perú, 1993)

Vista la lectura del artículo antes mencionado, debemos hacer hincapié, que la importancia de este artículo radica en la búsqueda del respecto del carácter vinculante de los contratos, sin que exista intervención estatal. Por otro lado, tenemos un aspecto de especial relevancia, en lo referente a los contratos-ley, en los cuales el Estado otorga diferentes garantías a fin de promover la inversión del sector privado, renunciando incluso a su Ius Imperium, ya que no permite que sean modificados por las partes, de este modo el Estado y el privado, se comportan como iguales.

Este artículo fue interpretado por el Tribunal Constitucional en la Acción de Inconstitucionalidad 00005-2003-AI, en la demanda planteada por el Congresista Jonhy Lescano Ancieta contra la Ley 26285 que autorizó la suscripción del "contrato-ley” con Telefónica del Perú. Esta acción claramente buscaba dejar sin efecto "el contrato-ley" suscrito con Telefónica del Perú, para ello es analizado entre otras disposiciones el Artículo $62^{\circ}$ de la Constitución, y el Artículo 200 numeral 4 del mismo cuerpo legal referente a si el Tribunal Constitucional puede declarar la inconstitucionalidad del Contrato-Ley o de un contrato con fuerza de ley.

Al respecto el Tribunal Constitucional, analiza los mismos, y precisa en su considerando 16 que el contrato-ley es "un acuerdo de voluntades entre dos partes, que rige para un caso concreto, sólo que está revestido de una protección especial, a fin de 
que no pueda ser modificado o dejado sin efecto unilateralmente por el Estado... El blindaje del contrato-ley de manera alguna lo convierte en ley (...); únicamente obliga a las partes que lo acordaron, en ejercicio de su libertad contractual, y dentro de su relación jurídico patrimonial"; y en lo que respecta al contrato con fuerza de ley, su carácter vinculante proviene del artículo 39 del Decreto Legislativo $\mathrm{N}^{\circ} 757$ - Ley Marco para el Crecimiento de la Inversión Privada, norma que precisa que los convenios de estabilidad jurídica se celebran al amparo del Artículo $1357^{\circ}$ del Código Civil y tienen la calidad de contratos con fuerza de ley, de manera que no pueden ser modificados unilateralmente por el estado. (Sentencia $N^{\circ}$ 00005-2003-AI, 2003)

Ahora, revisando el Artículo $1357^{\circ}$ del Código Civil, encontramos que dicho texto señala:

"Por ley, sustentada en razones de interés social, nacional o público, pueden establecerse garantías y seguridades otorgadas por el Estado mediante contrato."

Como se puede ver de las referidas normas, El Estado puede otorgar garantías y seguridades a los inversionistas y/o receptores de inversión, y en ese caso, es como si actuaran entre iguales, siendo el objeto de dichas normas reducir el riesgo de inseguridad propia de la política económica, fiscal y social coyuntural (Valle Billingurst, 2006. p 254).

Ahora, analizaremos el Artículo $74^{\circ}$ de la Constitución Política del Estado, a efectos de interpretarlo en conjunto con el Artículo $62^{\circ}$ de la Constitución antes referida. El Artículo $74^{\circ}$ señala lo siguiente:

"Los tributos se crean, modifican o derogan, o se establece una exoneración, exclusivamente por ley o decreto legislativo en caso de delegación de facultades, salvo los aranceles y tasas, los cuales se regulan mediante decreto supremo.

Los Gobiernos Regionales y los Gobiernos Locales pueden crear, modificar y suprimir contribuciones y tasas, o exonerar de éstas, dentro de su jurisdicción, y con los límites que señala la ley. El Estado, al ejercer la potestad tributaria, debe respetar los principios de reserva de la ley, y los de igualdad y 
respeto de los derechos fundamentales de la persona. Ningún tributo puede tener carácter confiscatorio.

Las leyes de presupuesto y los decretos de urgencia no pueden contener normas sobre materia tributaria. Las leyes relativas a tributos de periodicidad anual rigen a partir del primero de enero del año siguiente a su promulgación.

No surten efecto las normas tributarias dictadas en violación de lo que establece el presente artículo.” (Congreso del Peru)

El artículo antes citado regula la potestad tributaria del estado para crear tributos, respetando el principio de reserva de ley, de igualdad y respeto de los derechos fundamentales, sin embargo, debe aplicarse el principio de coherencia normativa recogido por la sentencia del Tribunal Constitucional $\mathrm{N}^{\circ} 00005-2003-\mathrm{AI}$ que señala que:

"Dicha noción implica la existencia de la unidad sistémica del orden jurídico, lo que, por ende, presume una relación armónica entre las normas que lo conforman.

Ello es así por la necesaria e imprescindible compenetración, compatibilidad y conexión axiológica, ideológica y lógica entre los deberes y derechos asignados, además de las competencias y responsabilidades establecidas en el plano genérico de las normas de un orden jurídico."

Ahora, si bien, en principio podría alegarse que no resultarían compatibles el Artículo $74^{\circ}$ de la Constitución con el Artículo $62^{\circ}$ de la referida norma, debemos contemplar que el Tribunal Constitucional señaló en el considerando 34 de la sentencia $\mathrm{N}^{\circ}$ 00005-2003-AI que:

"Por su propia naturaleza, a través del contrato-ley, el Estado busca atraer inversiones privadas (de capital) a fin de que promuevan aquellas actividades que el Estado considera que vienen siendo insuficientemente desarrolladas, de acuerdo con los planes y objetivos que se pueda haber trazado en el diseño de la política 
económica del Estado. Tienen como contenido propiciar un marco de seguridad a los inversionistas no sólo en asuntos privados de la administración, sino, también, en la prestación de actividades de derecho público."

De otro lado, tenemos que la sentencia del Tribunal Constitucional $N^{\circ} 0048-2004-$ PI/TC hace una distinción entre discriminación y diferenciación, respecto a ambas categorías señala:

"En principio, debe precisarse que la diferenciación está constitucionalmente admitida, atendiendo a que no todo trato desigual es discriminatorio; es decir, se estará frente a una diferenciación cuando el trato desigual se funde en causas objetivas y razonables. Por el contrario, cuando esa desigualdad de trato no sea ni razonable ni proporcional, estaremos frente a una discriminación y, por tanto, frente a una desigualdad de trato constitucionalmente intolerable."

Más adelante añade:

"Por otro lado, debe tenerse en consideración que el Estado en algunas oportunidades promueve el trato diferenciado de un determinado grupo social, otorgándoles ventajas, incentivos o, en general, tratamientos más favorables. Esto es lo que en doctrina constitucional se conoce como "discriminación positiva o acción positiva -affirmative action-“". La finalidad de esta acción afirmativa no es otra que compensar jurídicamente a grupos marginados económica, social o culturalmente; persigue, pues, que dichos grupos puedan superar la inferioridad real en la que se encuentran con acciones concretas del Estado.”

A efectos de saber si se está frente a una ruptura del derecho constitucional a la igualdad, el Tribunal Constitucional usa el Test de Razonabilidad el cual "como ha señalado la Corte Constitucional de Colombia (Sentencia N. ${ }^{\circ}$ C-022/96), es una guía metodológica para determinar si un trato desigual es o no discriminatorio y, por tanto, 
violatorio del derecho-principio a la igualdad. Dicho test se realiza a través tres subprincipios:

1. subprincipio de idoneidad o de adecuación;

2. subprincipio de necesidad; $y$

3. subprincipio de proporcionalidad strictu sensu."

En el caso concreto, cuando el estado da garantías y seguridades a ciertas inversiones a través de los contratos ley, sin duda genera diferencias, ya que hay particulares que no podrían acceder a la invariabilidad del régimen, sin embargo, ello no implica que se afecte el principio de igualdad, por cuanto existen causas objetivas y razonables que justifican la diferenciación en el trato, sobre todo cuando en aplicación del test de razonabilidad, se observa que el estado busca llegar a fines constitucionalmente legítimos como son el desarrollo social y económico del país y la libertad de empresa recogidos en los Artículos 23 y 59 de la Constitución. (Valle Billinghurst, 2006. P. 251252)

Como consecuencia de lo expuesto, es evidente que los convenios de estabilidad son constitucionalmente legítimos, no afectan la potestad tributaria, no existiendo discriminación, sino una diferenciación para un fin constitucionalmente legítimo y que finalmente, se cumpla con el objetivo de obtener mayores inversiones para el país y una mayor recaudación.

\subsection{De la promoción de la inversión privada.}

\subsubsection{Las privatizaciones.}

La inversión privada ha venido siendo promovida con mayor intensidad desde inicios de la década del 90, y para ello fue necesario emprender reformas que tuvieron este objetivo. Es en estas circunstancias que dictaron el Decreto Legislativo 662 (Ley de Régimen de estabilidad jurídica a las inversiones extranjeras), Decreto Legislativo 674 (Ley de Promoción de la Inversión privada de las empresas del Estado), el Decreto Legislativo 757 (Ley Marco para el crecimiento de la inversión privada) y el Decreto 
Legislativo 758 (Ley que promueve las inversiones privadas en la infraestructura de servicios públicos).

En este capítulo vamos a ir adentrándonos en lo que respecta a la promoción de la inversión privada a través de los decretos Legislativos 674 y el Decreto Legislativo 758, así como sus normas sustitutorias y modificatorias. En el siguiente capítulo, ahondaremos en mayor detalle en o que corresponde a los convenios de estabilidad.

En lo que respecta al Decreto Legislativo 674, debemos de considerar los antecedentes, para entender el contexto de la norma. Hasta antes de 1990, el Estado peruano había amasado una cantidad grande de activos, ya sea creando empresas públicas o expropiándolas de su propiedad a los privados. Así, a inicios de la década del noventa, se buscaba incentivar la inversión privada, y el estado por su parte buscaba abandonar la Actividad Empresarial del Estado, ya que ello había ocasionado crisis económicas con efectos bastante severos para el país.

Con el Decreto Legislativo 674, se buscaba que el Estado peruano fuera abandonando la Actividad Empresarial del Estado, bajo las modalidades previstas en el Artículo $2^{\circ}$ a saber:

“a) La transferencia del total o de una parte de sus acciones y/o activos, en este último caso, incluso mediante la permuta de bienes inmuebles, en cuyo caso serán de aplicación las normas que regulan el Sistema Nacional de Bienes Estatales.”

b. El aumento de su capital.

c. La celebración de contratos de asociación, “joint venture”, asociación en participación, prestación de servicios, arrendamiento, gerencia, u otros similares.

d. La disposición o venta de sus activos, cuando ello se haga con motivo de su disolución y liquidación.” (Decreto Legislativo 674).

La aplicación de dicha norma dio a lugar a un proceso de privatización de diversas empresas de propiedad del estado, así como de sus activos; precisando que por Ley 28244 
publicada el 03 de junio del 2004, se decidió por excluir a Petroperú de las modalidades de inversión privada en las modalidades de transferencia de acciones o disposición o venta de activos.

\subsubsection{Asociaciones público-privadas.}

El Decreto Legislativo 758 publicado el 13 de noviembre de 1991, dictó las normas de promoción de inversiones en la infraestructura de servicios públicos, en concesiones a personas jurídicas, nacionales o extranjeras, para la construcción, reparación, conservación y explotación de obras de servicios públicos.

Con fecha 27 de diciembre de 1996, se publicó el TUO de las normas con rango de ley que regulan la entrega en concesión al sector privado de las obras publicas de infraestructura y de servicios públicos - Decreto Supremo $\mathrm{N}^{\circ}$ 059-96-PCM, allí se unificaron en un solo texto el Decreto Legislativo 758 y Decreto Legislativo 839.

Mediante Decreto Legislativo 1012, se aprobó la Ley marco de asociaciones público- privadas en las que participaba la inversión privada con el objeto de crear, desarrollar, mejorar, operar o mantener infraestructura pública o proveer servicios públicos. Posteriormente, dicha norma fue ampliada por la Ley 30167 con la finalidad de prestar los servicios vinculados a los servicios públicos que requiera brindar el Estado, así como desarrollar proyectos de investigación aplicada y/o innovación tecnológica.

Posteriormente, el Decreto Legislativo 1224 estableció un marco normativo unificado para la promoción de la inversión privada mediante asociaciones público privadas y proyectos en activos, buscando además alinearse a los estándares de la OCDE. Cabe precisar, que la Única Disposición Complementaria Derogatoria de la citada norma, derogó el Decreto Legislativo 1012, así como el Decreto Supremo Nº59-96-PCM, con excepción del primer y segundo párrafo del artículo 19 y el artículo 22 de esta última norma. Cabe precisar, que estas normas aún subsistentes tienen relación directa con el régimen tributario de las concesiones, sobre el cual pasaremos a pronunciarnos en el punto 2.6 del siguiente capítulo.

Actualmente, la norma vigente que regula las Asociaciones Públicos Privadas y proyectos en Activos - Decreto Legislativo 1362, y esta sustituyó el Decreto Legislativo 
1224, conforme lo precisa la exposición de motivos, en razón a que la normatividad respecto a las asociaciones público-privadas no se encontraba debidamente sistematizada, era poco clara, no tenía un adecuado nivel de transparencia y predictibilidad de las entidades, no conseguía un adecuado seguimiento y acompañamiento de proyectos, ocasionaba cancelación o abandono de proyectos, generaba restricciones a la competencia para las iniciativas privadas, no tenía un registro contable de proyectos alineado a las normas internacionales de contabilidad para el sector público, etc.

El Decreto Legislativo 1362 que regula la promoción de la inversión privada mediante asociaciones público-privadas y proyectos en activos, buscó corregir la problemática antes mencionada, en aras de obtener mayor resultado en la ejecución de proyectos.

En esta norma queda claro en el Artículo 21.2 que los proyectos de Asociación público- privadas que recaigan sobre bienes públicos, no otorgan al inversionista un derecho real sobre los mismos; manteniéndose en el artículo 22 la clasificación de las asociaciones público-privadas en cofinanciadas y autofinanciadas. El desarrollo de las asociaciones público-privadas se desarrolla en diversas fases como son el: planeamiento y programación, formulación, estructuración, transacción y ejecución contractual.

\subsection{De las concesiones en el sector minero.}

\subsubsection{De las concesiones mineras.}

Antes de iniciar el presente punto, considero pertinente identificar cuál es el ciclo productivo minero, antes de poder arribar a lo que son concesiones mineras. Esta se inicia con el cateo y la prospección, los cuales tienen por finalidad identificar la zona donde se podrá realizar la actividad minera. Identificada la zona, se procede a las actividades de exploración, por la que se realizan los estudios de la cantidad y calidad de mineral; igualmente se identifica que tan rentable sería la explotación en la zona donde se realizaría la actividad minera. Culminada la etapa de exploración, sigue la etapa de desarrollo y construcción, en los cuales se tienen que ejecutar los trabajos de infraestructura para poder explotar y extraer el mineral. Después sigue la explotación, donde se obtiene y se procesa el mineral a efectos de su comercialización. Finalmente, sigue el cierre y postcierre, el cual se realiza al agotarse las reservas de mineral. 
El TUO de la Ley General de Minería, tiene una lista de posibles actividades a desarrollar en la industria minera, conforme lo prevé el Artículo VI del Título Preliminar de dicha norma, siendo las actividades reconocidas, el cateo, la prospección, la explotación, la labor general, el beneficio, la comercialización y el transporte minero, precisando el Artículo $7^{\circ}$ cuales de estas actividades están reguladas a través del sistema de concesiones.

En lo que respecta a las concesiones mineras, estas se encuentran recogidas en el Artículo $9^{\circ}$ del TUO de la Ley General de Minería según se precisa otorgan a su titular el derecho a explorar y explotar los recursos naturales concedidos, que se encuentren dentro de un sólido de profundidad indefinida. Para efectos legales, según la norma referida, la concesión minera es un inmueble distinto y separado del predio en donde se ubica, pudiendo tratarse de concesiones metálicas o no metálicas.

Entre las características que tiene la concesión minera son las siguientes:

a. Legal. - La ley fija sus condiciones para su utilización y otorgamiento.

b. Formal. - La ley establece el procedimiento, requisitos y como acto es reglado.

c. Irrevocable. - En tanto el titular cumpla con sus obligaciones: pago de derecho de vigencia y penalidad.

d. Derecho real. - Otorga el uso, disfrute y propiedad del recurso mineral concedido cuando ya se ha extraído.

e. Inmueble. - Distinto y separado del predio donde se ubica.

f. Tiene una unidad básica de medida.- Con una extensión mínima de 100 Has. (Ministerio Público)

\subsubsection{De las concesiones de beneficio.}

Las concesiones de beneficio se encuentran reguladas en el Artículo $17^{\circ}$ y $18^{\circ}$ del TUO de la Ley General de Minería - Decreto Supremo Nº14-92-EM, y concede a su titular el derecho a extraer o concentrar la parte valiosa de un agregado de minerales desarraigados y/o a fundir, purificar o refinar metales, mediante procesos físicos, químicos o físico químicos. (Decreto Supremo Nº14-92-EM) 


\subsubsection{De las concesiones de labor general.}

Este tipo de concesión se encuentra en los artículos $20^{\circ}$ y $21^{\circ}$ del del TUO de la Ley General de Minería - Decreto Supremo N 014-92-EM, y conceden a su titular el derecho de prestar servicios auxiliares a dos o más concesiones mineras. Un ejemplo de ello, serían los servicios de ventilación, desagües, o extracción de dos o más concesiones otorgadas a distintos concesionarios.

\subsubsection{De las concesiones de transporte minero.}

Este tipo de concesión se encuentra regulado por los artículos $22^{\circ}$ y $23^{\circ}$ del TUO de la Ley General de Minería - Decreto Supremo Nº 014-92-EM, y concede concesiones para el transporte masivo de mineral por métodos no convencionales, como son fajas transportadoras, tuberías o cable carriles; y otorga a su titular el derecho de instalar y operar dicho sistema entre uno o varios centros mineros y un puerto o planta de beneficio, o una refinería o uno o más tramos de estos proyectos. (Decreto Supremo No 014-92-EM)

\subsection{De los contratos del sector hidrocarburos.}

\subsubsection{Del contrato de licencia.}

El Contrato de Licencia es reconocido por el Artículo $10^{\circ}$ del Decreto Supremo $\mathrm{N}^{\circ}$ 042-2005-EM - TUO de la Ley Orgánica de Hidrocarburos y su naturaleza es sencilla. Bajo esta modalidad, PERUPETRO S.A. celebra un contrato de licencia con el contratista, quien obtiene la autorización de explorar y explotar o explotar hidrocarburos en un área geográfica determinada por el Contrato; por su parte PERUPETRO S.A. le transfiere el derecho de propiedad de los hidrocarburos extraídos al contratista, el cual debe pagar una regalía al Estado. (TUO de la Ley General de Hidrocaburos - Decreto Supremo Nº42-2005-EM, 2005)

Con relación a este tipo de contrato, cabe precisar que el riesgo de ejecución del contrato recae sobre el contratista, sin embargo, en caso de éxito, es la más rentable, ya que aquí la propiedad del hidrocarburo es del propio contratista una vez sea extraído, debiendo este solamente pagar una regalía al Estado. 


\subsubsection{Del contrato de servicios.}

Por este tipo de contrato, conforme al Artículo $10^{\circ}$ del Decreto Supremo $\mathrm{N}^{\circ}$ 0422005-EM - TUO de la Ley Orgánica de Hidrocarburos PERUPETRO S.A. celebra con el Contratista un acuerdo por el cual este último, procederá a las actividades de exploración y explotación o solo de hidrocarburos en el área determinada por el contrato; y como contraprestación el contratista recibe una retribución en función a la producción fiscalizada de hidrocarburos. (TUO de la Ley General de Hidrocaburos - Decreto Supremo Nº42-2005-EM, 2005).

Con relación a este tipo de contrato, se precisa que el riesgo de la ejecución del contrato es de PERUPETRO S.A., en ningún momento PERUPETRO S.A. transfiere la propiedad del hidrocarburo, los riesgos son asumidos por esta entidad, y lo que paga a el contratista es una contraprestación por el trabajo hecho. En términos de costo beneficio, diríamos que no es tan rentable como la anterior forma de contratación, pero esto se debe también al nulo riesgo para el contratista.

\subsubsection{Otros tipos de contratos.}

Respecto a este último punto, el inciso c) del Artículo del Decreto Supremo $\mathrm{N}^{\circ}$ 042-2005-EM - TUO de la Ley Orgánica de Hidrocarburos, dicha norma solo señala que se trata de otras modalidades de contratación autorizadas por el Ministerio de Energía y Minas. Respecto a este punto, la citada disposición señala en forma expresa a que se refiere, sin embargo, se trata de contratos que el Estado puede celebrar para transporte de hidrocarburos, distribución de gas natural, etc. (Castagnino Abásalo)

\subsection{Conclusiones del presente capitulo.}

Después de analizar el texto constitucional, podemos concluir que esta prescrito que uno de los deberes del estado es la búsqueda del bienestar general y desarrollo equilibrado de la nación a través de los mecanismos adecuados.

Para alcanzar este fin, puede disponer que los recursos naturales que son parte del patrimonio de la nación puedan ser usufructuados en forma sostenible por el sector privado, quienes, para acceder a los mismos, se encontrarán obligados a realizar inversiones. 
Para canalizar las inversiones a realizarse por el sector privado, el Estado puede otorgar una serie de garantías y suscribir contratos con el sector privado, los cuales por si mismos, no implican una renuncia a su potestad tributaria, sino que buscan otorgarles a los particulares estabilidad jurídico-tributaria, a efectos de darle predictibilidad en la obtención de sus resultados.

Este trato diferenciado respecto a los demás contribuyentes tiene una finalidad superior, que es atraer la mayor cantidad de inversiones a efectos de obtener el desarrollo de la Nación y bienestar general, el cual es un acto justificado y no es arbitrario. Este tratamiento diferenciado, no busca necesariamente una mayor recaudación fiscal, sino atraer la mayor cantidad de inversiones que sea posible para el país.

El Estado tiene una serie de herramientas, para alcanzar sus fines a efectos de atraer las inversiones, ya sea mediante privatizaciones, asociaciones público-privadas $\mathrm{u}$ otorgamiento de concesiones; y en el ámbito sectorial, mediante concesiones mineras, contratos de licencias y de servicios, siempre teniendo en consideración que el aprovechamiento del patrimonio de la Nación sea en forma sostenible. 


\section{CAPÍTULO II: LOS CONVENIOS DE ESTABILIDAD EN EL SECTOR MINERO.}

\subsection{Importancia de sector minero en la economía peruana.}

Podemos señalar que en la actualidad el sector minero es una de las fuerzas que más interviene en el crecimiento de la economía, puesto que aporta el 10\% al Producto Bruto Interno (PBI), según el Instituto Peruano de Economía (Instituto peruano de Economía, 2018), así como divisas e ingresos fiscales como efecto de la recaudación. Estos tres puntos son cruciales para el país, recordemos que el año pasado el problema que tuvo Minera las Bambas con la población hizo disminuir el PBI del año y desencadenó problemas con los contratos de la empresa en relación con terceros, ya que paralizaron la producción al no tener un mayor almacén, por ende, paralizaron varios contratos de tercerización.

La minería genera múltiples beneficios en las localidades donde se instalan. Así tenemos que cuando una empresa minera inicia sus actividades, significa que la comunidad se beneficia en puestos de trabajo, en forma directa e indirecta produciéndose inclusive un efecto multiplicador a través del incremento del consumo.

Otro beneficio es la mejora en los servicios de salud, servicios públicos, educación, vías de comunicación, entre otros.

Finalmente, es importante recalcar que el Perú quedo en segundo lugar de Latinoamérica en el ranking mundial de minería según la compañía canadiense Fraser Institute. Perú quedo en el puesto catorce, mientras que Chile quedo en el puesto seis. El país vecino se impone al Perú en el "Índice de percepción de políticas", el cual es uno de los puntos del estudio. (Rumbo Minero)

\subsection{Razones económicas para la celebración de Convenios de Estabilidad.}

Los Convenios de estabilidad en nuestro país fueron creados para atraer inversión nacional y extranjera a cambio de otorgar un instrumento que brinde seguridad y estabilidad jurídica a los inversionistas. Con la suscripción de estos convenios, el Estado busca atraer la inversión necesaria a efectos de solucionar los principales problemas que 
le aquejan, como el desempleo, la pobreza, los conflictos sociales y la inestabilidad política, mejorando así el riesgo país.

En cuanto al riesgo-país, éste es un índice que mide el "peligro" que entraña un nación para las inversiones extranjeras, es decir es la sobretasa de interés que paga cada país para financiarse en mercados internacionales. A mayor riesgo-país, hay un incremento de peligro para las inversiones extranjeras y para el comercio exterior (Schreck, Marcial Garcia, 2005). Es por ello, que cada país busca un mejor rendimiento de las inversiones para tener un mejor rango crediticio y así obtener tasas más rentables para su economía.

Por el lado de los inversionistas, ellos son conscientes de la relación riesgo-beneficio, $\mathrm{y}$ conocen perfectamente que, para asumir un mayor riesgo, debe existir un mayor beneficio. La actividad minera de por su propia naturaleza, tiene ya un riesgo implícito, por cuanto es posible que pueda o no encontrar el mineral que se pretende explotar, y si a ello, le agregamos el riesgo político, se hace más difícil que el inversionista pueda arriesgar su capital.

A efectos, de disipar ese riesgo político, los convenios de estabilidad sirven para lograr que el inversionista esté en condiciones de tomar una decisión favorable para el proyecto a emprender.

Los Convenios de Estabilidad, traen ventaja para los inversionistas, toda vez que pueden medir por adelantado la carga tributaria que deberá soportar su actividad en el tiempo del contrato, para poder calcular su rentabilidad. Otra ventaja, es que los inversionistas, pueden tener estabilidad tributaria, pese a los problemas sociales y políticos que pueden existir en el país que es objeto de la inversión, y no convertirse en "rehenes" de los gobiernos de turno, en caso, exista una mayor rentabilidad causada por el incremento en el precio de los minerales u otras circunstancias externas a la actividad.

Por parte del Estado, el beneficio es el aumento de las inversiones, más recaudación por impuestos, más puestos de trabajo, así como más obras públicas, ya sea por infraestructura vial, escuelas, centros de salud, entre otros que quedan en beneficio del país receptor de la inversión; incluso con la aplicación del régimen de obras por impuestos, las mismas empresas pueden financiar una obra con cargo al impuesto a la renta que habrá que pagar, beneficiando igualmente al país receptor de la inversión. 
En síntesis, en los convenios con estabilidad ganan las dos partes, la empresa y el Estado. Es importante aclarar, que los convenios de estabilidad no implican beneficios, ni privilegios fiscales, ni exoneraciones, solo es aplicar las normas impositivas vigentes que existan al momento de celebración del contrato por el tiempo establecido.

Teniendo en consideración lo antes expuesto, es que el Estado a fin de incentivar la inversión extranjera, en un primer momento promulgó el Decreto Legislativo 662; extendiendo posteriormente dicha estabilidad mediante Decreto Legislativo 757, a los inversionistas nacionales y extranjeros, ya sea que se trate personas naturales y jurídicas. Ambas normas, prevén las características principales, la fijación del plazo, monto y las condiciones del contrato establecida por las dos partes (El estado y el inversionista) y es considerado como contrato de rango de ley. Este convenio lo puede firmar un inversionista nacional o extranjero que quiera invertir en cualquier sector económico del país como agricultura, manufactura, obras de infraestructura, extracción de recursos naturales (minerales y petróleo) entre otros.

Debido a su nivel de importancia, tanto en capital invertido como en tributos materia de recaudación, el Estado ha creado convenios específicos establecidos para los regímenes sectoriales, teniendo especial importancia los convenios de estabilidad previstos en el TUO de la Ley General de Minería aprobado por Decreto Supremo No 014-92-EM y el TUO de la Ley Orgánica de Hidrocarburos, aprobado por Decreto Supremo $\mathrm{N}^{\circ}$ 042-2005-EM, las cuales tienen muchos más beneficios que los decretos legislativos 662 y 757.

\subsection{Cronología de los convenios de estabilidad en la legislación peruana.}

A continuación, pasaremos a hacer una breve cronología de los Convenios de Estabilidad, en el ámbito sectorial como el general, a partir de los Decretos Leyes 22774 y 22775 hasta la actualidad.

\subsubsection{De los Decretos Leyes 22774 y 22775 y las inversiones en el gobierno militar.}

En cuanto Hidrocarburos, los Decretos Leyes 22774 y 22775, ambos publicados el 07 de diciembre de 1979, preveían que la propiedad incluso del mineral extraído fuera de propiedad de Petroperú, y que esta empresa, les pague su retribución en especie a los contratistas, no previéndose ningún convenio de estabilidad relacionado al sector de 
hidrocarburos, debiéndose tomar en cuenta que dicha normatividad fue expedida por el Gobierno Militar siendo su objeto "asegurar la apropiada participación del Estado y promover la inversión privada".

\subsubsection{Del Decreto Legislativo 109 y las garantías contractuales.}

El 13 de junio de 1981 se publicó el Decreto Legislativo 109 - Ley General de Minería, el cual entró en vigor el 01 de septiembre de ese año, esté previó que el Estado pueda asegurar contractualmente garantías de estabilidad tributaria, conforme se verifica de los Artículos $155^{\circ}$ y $157^{\circ}$ de la indicada norma.

Es durante su periodo de vigencia que se celebra el Convenio de Estabilidad de fecha 25/09/1989, entre el Estado Peruano y la Compañía Minera Santa Luisa S.A., el cual es bastante extenso y detallado a diferencia de los que se suscribieron con posterioridad. En este convenio, un dato que hemos encontrado relevante, es que, en su cláusula decimocuarta, se indica que el plazo de duración del contrato será "el que se requiera para recuperar las inversiones en el proyecto que le ha dado origen". (Ministerio de Energía y Minas), lo cual no se podría dar en los Convenios de Estabilidad tributaria actuales, que tienen plazo determinado de 10, 12 y 15 años.

\subsubsection{Del Decreto Legislativo 662 y la promoción de la inversión extranjera.}

Después del Decreto Legislativo 109, tuvieron que pasar diez años para que se retomen las medidas legislativas a efectos de procurar la inversión y celebrar nuevos Convenios de Estabilidad. Así encontramos que mediante Decreto Legislativo 662 publicado el 02 de septiembre de 1991, se crearon los convenios de estabilidad, dirigida a los inversionistas extranjeros, siendo estos aplicables a todos los sectores, siempre que se cumplieran los requisitos de la indicada norma.

\subsubsection{Del Decreto Legislativo 708, que reguló los convenios de estabilidad mineros.}

Siguiendo la cronología, mediante Decreto Legislativo 708 publicado el 06 de noviembre de 1991, encontramos que se establecen los beneficios básicos para la promoción de la estabilidad tributaria, cambiaria y administrativa en el sector minero. 
2.3.6. Del Decreto Legislativo 757, que reguló la estabilidad de las empresas receptoras de la inversión, así como el Decreto Supremo $N^{\circ}$ 162-92-EF que reglamentó los Decretos 662 y 757.

Posteriormente mediante Decreto Legislativo 757 publicado el 13 de noviembre de 1991, se buscó ampliar que los beneficiarios de los Convenios de Estabilidad fueran personas naturales y jurídicas, así como inversionistas nacionales y extranjeros. Tanto el Decreto Legislativo 662 y 757, fueron reglamentados por el Decreto Supremo $\mathrm{N}^{\circ} 162$ 92-EF - Reglamento de los Regímenes de Garantía a la Inversión Privada, fija con mayor detalle los alcances de las garantías para los inversionistas nacionales o extranjeros y las empresas receptoras de inversión.

\subsubsection{Del TUO de la Ley General de Minería que unificó el Decreto Legislativo 101 y el Decreto Legislativo 708 y su reglamento aprobado por Decreto Supremo $\mathbf{N}^{\circ}$ 024-93-EM.}

El 03 de junio de 1992, se publicó el TUO de la Ley General de Minería - Decreto Supremo $\mathrm{N}^{\circ}$ 014-92-EM, el cual ya incorporó el texto final de los convenios de estabilidad que regulan el sector minero con todos los cambios previstos en el Decreto Legislativo 708. Por otro lado, debemos considerar que el Decreto Supremo No 024-93EM publicado el 07 de junio de 1993, reglamentó lo concerniente a las garantías previstas para la estabilidad minera.

\subsubsection{De la Ley Orgánica de Hidrocaburos y su aporte en lo que se refiere a} la estabilidad de los contratos.

Con fecha 20 de agosto de 1993, se publicó la Ley Orgánica de Hidrocarburos, la cual dentro de su ordenamiento reguló la estabilidad tributaria en el sector hidrocarburos, el cual abarcó toda la inversión que se realice en el contrato. 


\subsubsection{Del Decreto Supremo $\mathrm{N}^{\circ}$ 04-94-EM que reguló el modelo de contrato de estabilidad minero.}

Más adelante tenemos que el 09 de febrero de 1994, se publicó el modelo de contrato de garantías y medidas de promoción a la inversión minera - Decreto Supremo N ${ }^{\circ}$ 04-94EM, el cual es importante, ya que simplificó la celebración de estos convenios, siendo estos contratos por adhesión.

\subsubsection{De las leyes 27342 y 27343 que aumentaron en dos puntos porcentuales el impuesto a la renta estabilizado, tanto para la estabilidad en general como en los sectores mineros y de hidrocarburos.}

El 06 de septiembre del 2000, se publicó la Ley 27342, que reguló los Convenios de Estabilidad Jurídica de los Decretos Legislativos $\mathrm{N}^{\circ} 662$ y 757, incrementando el monto mínimo de inversión a US\$10’000,000.00 (Diez millones y 00/100 dólares de los Estados Unidos de América) para los sectores de minería e hidrocarburos, y no menor a US\$ 5’000,000.00 (Cinco millones y 00/100 dólares de los Estados Unidos de América) para los demás sectores. Se precisa que esta norma aumentó en dos puntos porcentuales el Impuesto a la Renta en los convenios recogidos en los Decretos Legislativos $\mathrm{N}^{\circ} 662$ y 757.

Por otro lado, por la Ley 27343 - Ley que regula los Contratos de Estabilidad con el Estado al amparo de las Leyes Sectoriales, se precisó que la estabilidad otorgada en el TUO de la Ley General de Minería y la Ley Orgánica de Hidrocarburos, estabilizaba únicamente impuestos vigentes, aplicándose en el caso de Impuesto a la Renta la tasa vigente a la fecha de suscripción del contrato más dos puntos porcentuales.

\subsubsection{De la ley 27391 que dejó sin efecto disposiciones perjudiciales de las leyes} 27342 y 27343.

Por Ley 27391, se dejó sin efecto el numeral 3.2 del Artículo 3 de la Ley No 27342 y el numeral 5.2 del Artículo 5 de la Ley $\mathrm{N}^{\circ} 27343$, toda vez que quitaba la vigencia de la estabilidad a los convenios de estabilidad en caso de que intervengan como parte interviniente en una reorganización de sociedades. 


\subsubsection{De la ley 27514 que dejó sin efecto los dos puntos adicionales al Impuesto a la Renta para convenios regulados en los Decretos Legislativos 662 y 757.}

Por la Ley 27514 publicada el 28 de agosto del 2001, se dejó sin efecto los dos puntos adicionales al Impuesto a la Renta que deberían de pagar quienes suscriban los convenios de estabilidad regulados en los Decretos Legislativos 662 y 757, y precisó que se estabiliza el Impuesto a la Renta que corresponda aplicar de acuerdo a las normas vigentes al momento de la suscripción del convenio correspondiente.

\subsubsection{De la Ley 27651 que promovió la formalización de pequeña minería artesanal.}

Cabe añadir que por Ley 27651 del 24 de enero del 2002 se reguló una norma que formalizaba y promovía la pequeña minería y la Minería artesanal, y modificó el Artículo $92^{\circ}$ del TUO de la Ley General de Minería a efectos de incorporar en la estabilidad de 10 años a los pequeños productores y productores mineros artesanales siempre que inviertan US\$ 500,000.00 (Quinientos Mil y 00/100 Dólares Americanos) y US\$ 50,000.00 (Cincuenta Mil y 00/100 Dólares Americanos) respectivamente.

\subsubsection{De la Ley 27909 que reguló las normas estabilizadas en el sector minero.}

Por Ley 27909, precisó que para los convenios de estabilidad que se suscriban al amparo de lo establecido en el Texto Único Ordenado de la Ley General de Minería, aprobado por Decreto Supremo No 014-92-EM, “estabilizarán el Régimen del Impuesto a la Renta vigente a la fecha de la celebración del convenio o contrato, siéndoles aplicables también las normas publicadas en el Diario Oficial El Peruano al momento de su suscripción que modifiquen dicho régimen, aunque entren en vigencia en ejercicios posteriores, siempre y cuando estas modificaciones se apliquen efectivamente de manera general." Asimismo, dicha norma, precisa que los dos puntos porcentuales a que se refiere la Ley 27343, se aplican sobre la tasa de Impuesto a la Renta de tercera categoría a que se refiere el Artículo $55^{\circ}$ del TUO de la Ley de Impuesto a la Renta. 


\subsubsection{Del TUO de la ley Orgánica de Hidrocarburos y la consolidación en un solo cuerpo legislativo de las modificatorias de la Ley 26221.}

Finalmente, mediante Decreto Supremo No 042-2005-EM se publica el TUO de la Ley Orgánica de Hidrocarburos, la cual toma en consideración las normas que modificaron la Ley 26221, lo cual dio merito a republicar la citada norma considerando las modificatorias actualizadas.

\subsection{Evolución de los Convenios de Estabilidad Tributaria en el TUO de la Ley General de Minería aprobado por Decreto Supremo 014-92-EM y sus normas modificatorias.}

En este sub capitulo desarrollaremos como ha ido evolucionando la legislación de los Convenios de Estabilidad Tributaria previstos en el TUO de la Ley General de Minería y sus normas modificatorias.

\subsubsection{Del texto original del TUO de la Ley General de Minería (Texto original)}

Para empezar, tal como lo hemos detallado en puntos anteriores, el TUO de la Ley General de Minería aprobado por Decreto Supremo 014-92-EM, viene de la fusión de la Ley General de Minería aprobada por Decreto Legislativo 109, sus normas modificatorias, así como las normas de promoción del sector minero del Decreto Legislativo 708. Dicha norma fue reglamentada por Decreto Supremo Nº24-93-EM publicado el 07 de junio de 1993.

Entre las características más destacables del TUO de la Ley General de Minería aprobado por Decreto Supremo 014-92-EM, es la existencia de convenios de estabilidad tributaria de 10 y de 15 años, tienen los siguientes beneficios y requieren de los siguientes requisitos:

\begin{tabular}{|l|l|l|l|l|}
\hline Plazo de & Inversión & Otros & Beneficios & $\begin{array}{l}\text { Posibilidad de } \\
\text { Estabilidad }\end{array}$ \\
mínima & requisitos & & estabilantar la \\
& & & \\
\hline
\end{tabular}




\begin{tabular}{|c|c|c|c|c|}
\hline $\begin{array}{lr}10 & \text { años } \\
(\text { Artículo } & 78^{\circ} \\
\left.\text { y } 79^{\circ}\right) & \end{array}$ & US\$ 2 millones & $\begin{array}{l}\text { Iniciar o realizar } \\
\text { actividades } \\
\text { mayores } \\
\text { 350/TM día } \quad \text { y } \\
\text { hasta } \quad 5,000 \\
\text { TM/día }\end{array}$ & 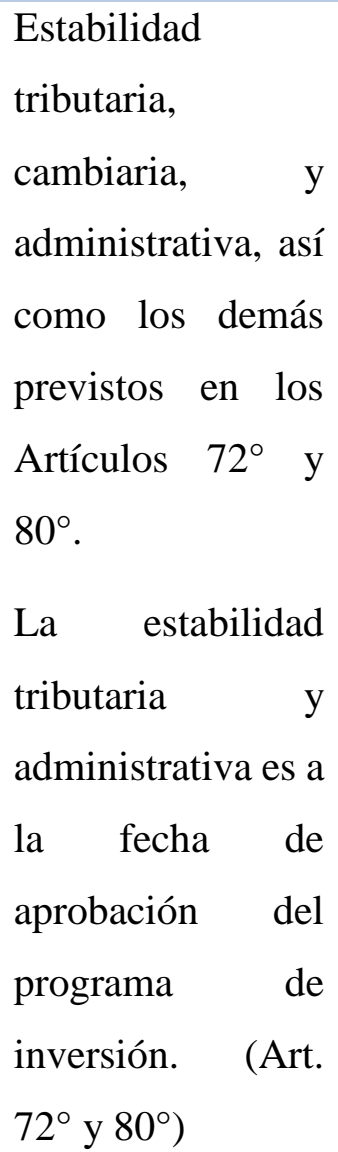 & $\begin{array}{l}\text { A la etapa de } \\
\text { inversión con } \\
\text { un máximo de } 3 \\
\text { ejercicios } \\
\text { consecutivos }\end{array}$ \\
\hline $\begin{array}{l}15 \text { años } \\
\text { (Artículo } 82^{\circ} \text { ) }\end{array}$ & $\begin{array}{l}\text { US\$ } 20 \text { millones } \\
\text { y US\$ } 50 \\
\text { millones en caso } \\
\text { de ampliaciones }\end{array}$ & $\begin{array}{l}\text { Capacidad } \\
\text { inicial no menor } \\
\text { de 5,000 TM/día } \\
\text { o ampliaciones } \\
\text { destinadas a } \\
\text { llegar a 5,000 } \\
\text { TM/día } \\
\text { referentes a } \\
\text { una o más UEA }\end{array}$ & $\begin{array}{l}\text { Estabilidad } \\
\text { tributaria, } \\
\text { cambiaria, } \\
\text { administrativa, así } \\
\text { como los demás } \\
\text { previstos en los } \\
\text { Artículos } 72^{\circ} \text { y } \\
80^{\circ} \text {, así como la } \\
\text { tasa de } \\
\text { depreciación de } \\
\text { máquinas y demás } \\
\text { activos fijos hasta } \\
\text { el } 20 \%\end{array}$ & $\begin{array}{l}\text { A la etapa de } \\
\text { inversión con } \\
\text { un máximo de } 8 \\
\text { ejercicios } \\
\text { consecutivos }\end{array}$ \\
\hline
\end{tabular}


En este punto hay que precisar que el segundo párrafo del Artículo $82^{\circ}$ del TUO original establecía que las UEA además de ser el conjunto de concesiones mineras del artículo $44^{\circ}$ de la ley, incorporaban a las plantas de beneficio y demás bienes que constituyan una sola unidad de producción, por razón de comunidad de abastecimiento, administración y servicios, según lo califique la Dirección General de Minería. Respecto a lo previsto en párrafo citado, lo consideramos importante, ya que guarda relación respecto a qué inversiones se encuentran estabilizadas conforme a los Convenios de Estabilidad mineros. Por otro lado, es preciso, tener en cuenta, que si bien los Artículos $78^{\circ}$ y $82^{\circ}$ del TUO de la Ley General de Minería hacen referencia a que los titulares de la actividad minera, son los que gozarán de la estabilidad tributaria, también tenemos que el Artículo $22^{\circ}$ del Reglamento de Garantías y Medidas de Promoción en la actividad minera - Decreto Supremo $\mathrm{N}^{\circ}$ 024-93-EM señala: “Las garantías contractuales, beneficiarán al titular de la actividad minera exclusivamente por las inversiones que realice en las concesiones o Unidades Económico-Administrativas."

En el sentido que la estabilidad prevista en la Ley General de Minería, solo garantiza la inversión se pronuncia el Informe 166-2007-SUNAT/2B0000 que señala: "La estabilidad tributaria garantizada mediante contrato suscrito con el Estado al amparo del Título Noveno del Texto Único Ordenado de la Ley General de Minería, beneficia al titular de la actividad minera por el plazo de 15 años sólo por las inversiones realizadas que se encontraban previstas en el Estudio de Factibilidad, teniendo en cuenta el monto definitivo que demandó para su ejecución en determinada concesión o Unidad Económico-Administrativa."

Ello a su vez es reiterado en las RTF $\mathrm{N}^{\circ}$ 18397-10-2013 así como la RTF $\mathrm{N}^{\circ}$ 08252-12013, las cuales reconocen que el régimen de estabilidad comprende solo el proyecto de inversión específico. Más adelante al analizar la casuística, respecto a las inversiones comprendidas en el convenio de estabilidad, procederemos a hacer nuestras críticas al respecto. 


\subsubsection{Modificaciones realizadas por el Decreto Ley 26121 publicado el 30 de diciembre de 1992.}

Por Decreto Ley 26121 del 30 de diciembre de 1992, se incorporó un segundo párrafo al TUO de la Ley General de Minería - Decreto Supremo 014-92-EM, así encontramos que a la estabilidad de 15 años se le añadió la posibilidad de llevar la contabilidad en moneda extranjera, lo cual tiene mucho sentido, ya que la "moneda funcional" conforme a la NIC 21 en la actividad minera es el dólar americano, por ser la moneda en que se venden los minerales y ser la moneda en la cual se generan los fundos de las actividades de financiación y se mantienen los importes cobrados por las actividades de operación. (Consejo Normativo de Contabilidad, 2018)

\subsubsection{Modificaciones realizadas por la Ley 27341 publicada el 18 de agosto del 2000.}

La Ley 27341, reviste particular importancia por cuanto reduce la facultad de ampliar la tasa anual de depreciación para los convenios de estabilidad de 15 años, respecto a las edificaciones y construcciones, llevando la tasa de depreciación de estos al límite máximo de 5\% anual. Esto es muy importante, ya que la depreciación es de especial importancia, ya que reduce la cantidad de impuestos a pagar a la administración tributaria. Si bien, consideramos que esto se ajusta a lo previsto en la Ley de Impuesto a la Renta, ello tuvo impacto en el sector minero, considerando los montos de inversión que hacen en edificaciones y construcciones por la misma actividad minera.

\subsubsection{Modificaciones realizadas por la Ley 27343 publicada el 06 de septiembre del} 2000.

La Ley 27343, es muy importante, ya que modifica la estabilidad tributaria del TUO de la Ley General de Minería, y la restringe, precisando que a partir de esa fecha, se otorgará garantía de estabilidad tributaria que incluirá únicamente a los impuestos vigentes. Con esto queda claro, que no se encuentran dentro los tributos estabilizados, las tasas y contribuciones.

Esta norma, también trajo consigo, que al impuesto a la renta estabilizado debería de adicionarse dos puntos porcentuales. De este modo, si por ejemplo, la tasa del impuesto a la renta estabilizado es de $29.5 \%$, se le deben de añadir $2 \%$ puntos, con lo cual el 
contribuyente con estabilidad deberá pagar un total de $31.5 \%$ de tasa del impuesto a la renta estabilizado.

Esta sobretasa, la consideramos cuestionable ya que dicha norma, en lugar de promover la inversión, la penaliza con dos puntos porcentuales. Cabe precisar que esta sobretasa había sido impuesta también en la Ley 27342 para los Convenios de estabilidad de los Decretos Legislativos 662 y 757, sin embargo, ello fue rápidamente descartado por la Ley 27514 publicada el 28 de agosto del 2001, que procedió a derogar dicha sobretasa.

Volviendo al análisis de la Ley 27343, otro aspecto relevante, es que la fecha de suscripción del convenio es la fecha que se toma en cuenta para determinar la estabilidad en el Impuesto a la Renta; y se establece la perdida de la estabilidad otorgada en caso de reorganización de sociedades si alguno de los intervinientes fuera titular de un convenio, sin embargo, ello fue derogado por la Ley 27391 publicado el 30 de diciembre del 2000.

\subsubsection{Modificaciones realizadas por la Ley 27909 publicada el 08 de enero del 2003}

Consideramos que esta norma, es de particular importancia, por cuanto deja en claro que normas son aplicables dentro de la estabilidad. Así tenemos que en el Artículo $1^{\circ}$ de dicha norma se señala lo siguiente:

"Los Convenios que se suscriban al amparo de lo establecido en los Decretos Legislativos $N^{o}$ s. 662 y 757 y los contratos que se suscriban al amparo de la Ley $N^{o} 26221$ - Ley Orgánica de Hidrocarburos, así como los contratos de garantía y medidas de promoción a la inversión minera, que se suscriban al amparo de lo establecido en el Texto Único Ordenado de la Ley General de Minería, aprobado por Decreto Supremo No 014-92-EM, estabilizarán el Régimen del Impuesto a la Renta vigente a la fecha de la celebración del convenio o contrato, siéndoles aplicables también las normas publicadas en el Diario Oficial El Peruano al momento de su suscripción que modifiquen dicho régimen, aunque entren en vigencia en ejercicios posteriores, siempre y cuando estas modificaciones se apliquen efectivamente de manera general. En tal sentido, las modificaciones aún no vigentes al momento de la suscripción del convenio serán de aplicación sólo a partir de su vigencia general; por lo que, en el supuesto que dicho régimen no 
entrase en vigencia por haber sido modificado o derogado con posterioridad a la suscripción del convenio, éste queda automáticamente excluido del convenio de estabilidad.

Lo dispuesto en esta norma será aplicable inclusive a los convenios y contratos que se encuentren en trámite ante el organismo competente."

Con esto queda claro, que no se tomarán en cuenta, para efectos del Convenio estabilizado, las modificaciones no vigentes, por más que hayan sido publicadas, si es que no tienen alcance general.

Respecto a este tema, hubo un informe el $\mathrm{N}^{\circ}$ 033-2016-SUNAT, en la que se consultó si de suscribirse un Convenio de Estabilidad, al amparo del TUO de la Ley General de Minería o entre otros, le era aplicable las tasas del impuesto a la Renta de tercera categoría correspondientes al ejercicio gravable 2015 en adelante, y si estás formaban parte del régimen tributario estabilizado. A efectos de poner en contexto este informe, por la Ley 30296 se modificó el Artículo 55 del TUO de la Ley de Impuesto a le Renta, disponiendo dicha norma, que se aplicasen las tasas de 28\% (ejercicios 2015-2016), 27\% (2017-2018) y 26\% (2019 en adelante), entrando en vigor dicha norma a partir del 01 de enero del 2015. En aquella ocasión la administración tributaria tuvo que interpretar el Artículo $1^{\circ}$ de la Ley 27909, y concluyó que todas las tasas previstas por la Ley 30296 se encontraban dentro del régimen tributario estabilizado, precisando que dicha norma se encontraba vigente, pese a que las tasas de $27 \%$ y $26 \%$ aún no habían entrado en vigor por un aspecto temporal.

Ahora volviendo a la Ley 27909, también encontramos que aclaró los alcances de la Ley 27343, precisando que los dos puntos adicionales de sobretasa al Impuesto a la Renta en los convenios de estabilidad sectoriales, solo eran para efectos del impuesto a la renta de tercera categoría.

En este punto, detendremos el análisis del TUO de la Ley General de Minería y sus modificatorias, ya que la casuística en la aplicación del TUO de la Ley General de Minería empezó a traer problemas a los contribuyentes con Convenios de Estabilidad Tributaria, lo cual generó la posterior promulgación de las leyes 30230 y 30296, que cambiaron la forma de los convenios, generando un grave daño al país, por cuanto a partir de dichas 
normas, no se volvió a suscribir ningún nuevo convenio de estabilidad al amparo del TUO de la Ley General de Minería.

2.5.Problemática en el sector minero con convenios de estabilidad. Problemática relacionada a la estabilidad de la inversión en las concesiones mineras, así como de las inversiones adicionales no previstas en el contrato de estabilidad. - Caso Cerro Verde.

Ahora, analizaremos brevemente la problemática relacionada a la estabilidad de la inversión en las concesiones mineras, así como con las inversiones adicionales no previstas en los contratos de estabilidad tributaria celebrados al amparo del TUO de la Ley General de Minería - Decreto Supremo $N^{\circ}$ 014-92-EM. Para estos efectos tomaremos en consideración la norma estabilizada, teniendo en cuenta que Cerro Verde suscribió su Convenio de Estabilidad con el Estado peruano con fecha 13 de febrero de 1998 y que ya se había aprobado el estudio de factibilidad, lo cual le otorgó la Garantía de estabilidad tributaria.

La controversia surge cuando a raíz del Informe $N^{\circ} 166-2007-S U N A T$, en el que se le pregunta a la Administración Tributaria, entre otras cuestiones lo siguiente:

"Los titulares de la actividad minera gozan de estabilidad tributaria garantizada mediante contrato suscrito por el plazo de 15 años contados a partir del ejercicio en que se acredite la ejecución de la inversión o de la ampliación, según sea el caso; sin embargo, ¿se puede concluir, que en aplicación del artículo $83^{\circ}$ del TUO de la Ley General de Minería, dicho beneficio contractual sólo será aplicable hasta por el monto de la inversión aprobada?".

A partir de aquí, se abrió toda una problemática, ya que la respuesta de la Administración Tributaria fue la siguiente:

"La estabilidad tributaria garantizada mediante un contrato suscrito por el plazo de 15 años al amparo del TUO de la Ley General de Minería, beneficia al titular de la actividad minera sólo por las inversiones realizadas que se encontraban previstas en el Estudio de Factibilidad, teniendo en cuenta el monto definitivo que demandó para su ejecución en determinada concesión o Unidad Económica Administrativa.” 
De lo anterior se desprende que según la Administración Tributaria lo único que era estabilizado por los Contratos de Estabilidad, eran las inversiones que fueron previstas en el Estudio de factibilidad, lo cual generó un problema respecto a las inversiones adicionales no previstas en los mismos, las cuales quedaron fuera del régimen estabilizado, y por ende le eran aplicables las disposiciones del régimen general. Otra controversia que surgió era si efectivamente lo estabilizado era la inversión o si era la concesión o la UEA (Unidad Económica Administrativa).

A continuación, analizaremos el caso Cerro Verde el cual se encuentra en la Resolución del Tribunal Fiscal N 08252-1-2013, el cual a su vez está vinculado a la RTF $\mathrm{N}^{\circ}$ 08997-10-2013, en aquellas, la Administración Tributaria pretendió entre otros el pago de regalías mineras de los periodos de enero a diciembre del 2008 y el pago de regalías de diciembre del 2006 y de enero a diciembre del 2007 respectivamente. Precisamos que ambas resoluciones analizan el "Proyecto de Lixiviación de Cerro Verde", tratan respecto a la misma obligación, que es el pago de regalías mineras, es por

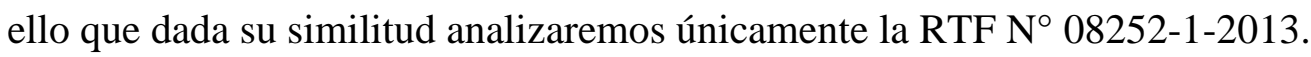

\subsubsection{Hechos expuestos en la $\mathrm{RTF} \mathrm{N}^{\circ}$ 08252-1-2013.}

Con fecha 13 de febrero de 1998, el Estado Peruano suscribió un Convenio de Estabilidad con Cerro Verde, a efectos de que esta última ejecute un plan de inversiones valorizados en US\$ 237’517,000.00 (Doscientos Treinta y Siete Millones Quinientos Diecisiete Mil y 00/100 Dólares Americanos) para ampliar la capacidad de producción de 72’000,000 a 105’000,000 de libras (48,000 TM) de cátodos de cobre por año, siendo el convenio de Estabilidad celebrado por 15 años, cuya vigencia se dio a partir de que se acredite la inversión realizada y esta sea aprobada por la Dirección General de Minería.

El plan de inversiones antes mencionado e incluido en el Estudio de Factibilidad comprendió labores, obras y adquisiciones, para poner en marcha el Proyecto de Lixiviación de Cerro Verde, el cual se ejecutaría a más tardar en 46 meses que vencían el 31 de diciembre de 1997.

Dicho convenio en la cláusula 4.2 permitía realizarse modificaciones y/o ampliaciones, siempre que no afecte el objeto final del Plan de Inversiones y sean aprobadas por la Dirección General de Minería. En el Anexo I, se incorporó el detalle de las concesiones 
afectadas entre las que se comprendió la Concesión Minera Cerro Verde $\mathrm{N}^{\circ} 01,02$ y 03 , así como la concesión de beneficio "Planta de Beneficio Cerro Verde".

Con fecha 23 de noviembre de 1998, se aprobó mediante Resolución Directoral N 342 98-EM/DGM la Declaración Jurada que acredita el cumplimiento de la Ejecución del Estudio de Factibilidad del "Proyecto de Lixiviación de Cerro Verde".

La solicitud de instalación de la planta que da lugar al "Proyecto de Sulfuros Primarios" se dio en el 2004, cuyo programa de Inversión por US\$ 800’030,000.00 (Ochocientos Millones Treinta Mil y 00/100 Dólares Americanos) se aprobó por Resolución Ministerial $\mathrm{N}^{\circ}$ 510-2004-EM, y que consistía en una Planta Concentradora para el tratamiento de sulfuros primarios de baja ley, que no son posibles de lixiviar.

En el informe $\mathrm{N}^{\circ}$ 156-2006-MEM-OGJ de fecha 16 de junio del 2006, se determinó por el Director General de la Oficina de Asesoría Jurídica del Ministerio de Energía y Minas, que el proyecto de sulfuros primarios no estaba previsto dentro del proyecto de lixiviación.

En el 2012, el Estado Peruano suscribió con el contribuyente un nuevo contrato de estabilidad, en la cual se incluía entre otros, instalaciones de procesamiento de sulfuros, por una inversión total aproximada US\$ 3,573’,407,000.00.

\subsubsection{Materia controvertida en la $\mathrm{RTF} \mathbf{N}^{\circ}$ 08252-1-2013.}

La controversia suscitada tiene su origen en la cobranza por parte de la Administración Tributaria de las regalías mineras de los periodos de enero a diciembre del 2008. Se precisa, que las regalías mineras, Ahora, haciendo un breve paréntesis, la deuda materia de cobranza, nace en mérito a la Ley N 28258 - Ley de Regalías Mineras, publicada el 24 de junio del 2004, reguló lo correspondiente a la regalía minera, y la definió como "una contraprestación económica que los titulares de las concesiones mineras pagan al Estado por la explotación de los recursos minerales metálicos y no metálicos.”, norma que fue posteriormente modificada por las leyes $\mathrm{N}^{\circ} 28323$ y 29788. La naturaleza de este gravamen minero no califica como tributo, por ende, es un recurso público originario, y se calcula sobre la utilidad operativa trimestral, conforme a las reglas fijadas en la mencionada Ley de Regalías mineras. 


\subsubsection{Argumento del contribuyente en la RTF $\mathrm{N}^{\circ} 08252-1-2013$.}

Para el contribuyente, su defensa empieza señalando que cuenta con una única concesión minera tiene una única concesión minera (Cerro Verde $\mathrm{N}^{\circ} 1, \mathrm{~N}^{\circ} 2$ y $\mathrm{N}^{\circ} 3$ ), la cual extrae todo el mineral y tiene una sola concesión de beneficios llamada "Planta de Beneficios Cerro Verde", la cual le ayuda con el proceso de extracción de minerales empleando los diversos sistemas de tratamiento.

Asimismo, el contribuyente señala que el régimen de estabilidad no puede comprender únicamente la inversión inicial para acceder a la suscripción del contrato expresada en el estudio de factibilidad, sino que debería alcanzar todas las inversiones y actividades relacionadas al negocio que la empresa lleve a cabo en las concesiones mineras o la unidad económica administrativa. Por lo que, si tiene estabilizado esta última, todo el mineral extraído de estas concesiones deberá estar en el mismo régimen tributario. Por lo cual no estaría sujeta al pago de regalías mineras, independientemente el proceso que siga para el tratamiento del mineral.

El contribuyente añade que la planta de beneficios, en el transcurso del tiempo ha sufrido varias ampliaciones y modificaciones que fueron debidamente aprobadas por la Dirección General de Minería mediante Resolución Directoral, la cual reconoce que estos cambios forman parte de la planta. Señala que en la Resolución Directoral antes referida se aprobó la instalación de la concentradora de flotación para tratar sulfuros primarios, y se reconoce que estás forman parte de la Planta de Beneficio Cerro Verde.

Por ende, el pago de las regalías mineras se da por la extracción o explotación de una concesión minera y no por el tipo de proceso posterior que se realice a este mineral. La interpretación que hace respecto al Artículo $83^{\circ}$ de la Ley General de Minería, es que la estabilidad tributaria comprende todas las actividades incluidas el tratamiento de mineral, que se realicen en las concesiones mineras o Unidades EconómicoAdministrativas incluidas en el contrato de estabilidad y no solo las contempladas en el estudio de factibilidad.

Añade que el Artículo $22^{\circ}$ del Reglamento de Garantías de Estabilidad Minera Decreto Supremo $N^{\circ}$ 024-93-EM no hace referencia que las inversiones estabilizadas sean las incluidas en el estudio de factibilidad; y que dicho artículo no obliga a llevar la contabilidad independiente por “proyectos de inversión” sino por concesión minera. 


\subsubsection{Argumento de la Administración Tributaria en la RTF $\mathbf{N}^{\circ}$ 08252-1-2013.}

La Administración Tributaria por su parte expresó que el contrato de estabilidad con el inversionista señalaba que la estabilidad se otorgaba únicamente a las actividades vinculadas al estudio de factibilidad; señalando también que el Proyecto de Sulfuros Primarios no formaba parte de la Planta de Beneficio Cerro Verde, y que fue incluida en el Convenio de Estabilidad con el Contribuyente. La Administración tributaria, añade que la finalidad de cada planta es distinta, la planta de lixiviación obtiene pureza de cátodos de cobre con $99 \%$ de pureza, y en el segundo concentrado de cobre con $26 \%$ de pureza y molibdeno. Finalmente, la Administración Tributaria reconoció que si bien la regalía minera, es una contraprestación económica de carácter administrativo, en lo que respecta a la Planta de Sulfuros Primarios, esta no se encontraba estabilizada.

\subsubsection{Posición del Tribunal Fiscal en la RTF $\mathbf{N}^{\circ}$ 08252-1-2013.}

El Tribunal Fiscal por su parte analizó el caso, y advirtió que existía una concentradora de flotación de sulfuros primarios que no forma parte del contrato de estabilidad de la Planta de Beneficio Cerro Verde. Al hacer un análisis de lo que es el Proyecto de lixiviación de Cerro Verde y lo que es el Proyecto de Sulfuros Primarios, pudo concluir que se tratan de busca beneficiar el mineral a través de métodos distintos con un grado de pureza distinto, lo cual no fue considerado en el contrato celebrado entre el Estado Peruano con el contribuyente, ni formó parte del Estudio de factibilidad, que originó el mismo.

En este caso, el contrato de estabilidad suscrito entre el Estado Peruano y el contribuyente fue analizado exhaustivamente, pudiéndose advertir en la cláusula primera que el contribuyente presentó su solicitud para que se garantice los beneficios relacionados a la inversión en su concesión Cerro Verde $\mathrm{N}^{\circ} 01,02$ y 03.

Que es en mérito a ello, que el Artículo $83^{\circ}$ del TUO de la Ley General de Minería exigió como requisito que se presente un programa de inversión, siendo exigido en el Artículo $85^{\circ}$ del mismo cuerpo legal y el reglamento, que se realice un estudio de factibilidad, con el fin de tenerse información sobre las condiciones, cronograma, plazo y monto de la inversión. 
En este análisis, es que se revisa el Artículo $20^{\circ}$ del Reglamento de Garantías de Estabilidad Minera, y establece que se puede modificar durante la ejecución el Estudio de Factibilidad, mientras que no se afecte el objeto final.

El Tribunal Fiscal añade que esa misma posibilidad de realizar modificaciones al estudio de factibilidad también se encontraba prevista en la cláusula del contrato de estabilidad suscrito entre el Estado Peruano y el contribuyente, al precisarse que podrían hacerse modificaciones y/o ampliaciones siempre que se realicen previamente a la Dirección General de Minería, para que sean incluidas en el plan de inversiones.

Más adelante, el Tribunal Fiscal al analizar los artículos $83^{\circ}$ del TUO de la Ley General de Minería y el Artículo $22^{\circ}$ del Reglamento de Garantías de Estabilidad Minera, precisa que el beneficio contractual recaerá exclusivamente en las actividades de la empresa a favor de la cual se efectué la inversión; siendo ello concordado con el mencionado reglamento, y precisando que las garantías contractuales solo benefician al titular de la actividad minera "exclusivamente por las inversiones que realice en las concesiones o Unidades Económico-Administrativas", añadiendo además que el Artículo $24^{\circ}$ del mismo reglamento, prevé que la Resolución Directoral que aprueba el Estudio de factibilidad es la que servirá de base para determinar las inversiones del contrato.

En atención a ello, es que el Tribunal Fiscal concluye:

"Que de lo antes expuesto y de las normas citadas se deduce que los beneficios de la estabilidad jurídica no se otorgan de manera general a favor del titular de la actividad minera o de alguna concesión minera determinada, sino con relación a un proyecto de inversión específico, claramente delimitado en el Estudio de Factibilidad, el cual ha sido aprobado por el Ministerio de Energía y Minas, por cuanto lo que se busca a través de estos contratos es de conferir seguridad jurídica al inversionista en el sentido que la tasa interna de retorno de su inversión no se vea afectada por nuevas disposiciones, siendo que en el caso bajo análisis, la inversión materia del contrato de estabilidad está referida al "Proyecto de Lixiviación de Cerro Verde", esto es, referida a la ampliación o mejoramiento del sistema de lixiviación de sulfuros secundarios."

En base a dicha interpretación, es que se termina concluyendo, que solo están estabilizadas las inversiones que fueron consideradas al realizar el estudio de factibilidad, 
y en este caso, concluye que el "Proyecto de Sulfuros Primarios" es otro programa de inversión distinto al de la "Planta de Beneficio Cerro Verde", y no se encontraba estabilizado. Como consecuencia de ello, se llegó a la misma conclusión que había llegado el Informe 166-2007-SUNAT. Por estas consideraciones, es que como resultado final se confirma las resoluciones de intendencia que fueran objeto de apelación ante el Tribunal Fiscal.

\subsubsection{De la Casación $N^{\circ}$ 5212-2016-LIMA.}

Pero este caso, no termina aquí, que es lo más interesante del asunto, sino que sigue y termina en el Poder Judicial, al menos con respecto a la RTF $N^{\circ} 8252-1-2013$ que fue materia de proceso contencioso administrativo.

Este caso, llegó hasta la Tercera Sala de Derecho Constitucional y Social Transitoria de la Corte Suprema de Justicia de la República, siendo finalmente resuelto mediante Casación N 5212-2016-LIMA.

Para resumir, al interponer demanda, el contribuyente ganó parcialmente en primera instancia; sin embargo, la sentencia de primera instancia fue revocada en la Corte Superior y se declaró infundada la demanda, quien hizo una interpretación conjunta de las cláusulas del contrato de estabilidad, sobre todo con la cláusula primera referida a la solicitud, en la que se solicitó que se le garantice los beneficios en relación con la inversión en la concesión minera. En los antecedentes de la cláusula primera, se precisó que el objetivo era ampliar la capacidad de producción, procedentes de la lixiviación en pilas de mineral de cobre.

Para la Sala Superior, quedó claro, que se estabilizaba únicamente dicha inversión, más aún del análisis de las cláusulas segunda a quinta, así como las sétima y octava del Convenio de Estabilidad, en la que quedaba claro que el estudio de factibilidad no era un simple requisito para acceder al beneficio, sino que era el sustento para la aprobación y desarrollo del proyecto. Añade la Sala, que conforme al Artículo $62^{\circ}$ de la Constitución del Estado, no se puede ir más allá de las reales declaraciones de voluntad de las partes, tal como lo pretende el contribuyente. Asimismo precisó que los beneficios contractuales conforme a los Artículos $83^{\circ}$ del TUO de la Ley General de Minería y el Artículo $22^{\circ}$ del Reglamento de Garantías de Estabilidad Minera, prevén que la estabilidad recaiga 
exclusiva y excluyentemente en la inversión ejecutada en la concesión minera, no pudiendo inferirse que las inversiones futuras estén cubiertas con el convenio de estabilidad, no pudiendo aplicarse dichos beneficios en forma amplia, como es para el caso del Proyecto de Sulfuros Primarios. La Sala también señala, que no existe impedimento para ampliar el Convenio de Estabilidad frente a futuras inversiones, lo cual depende de la voluntad de las partes.

Contra lo resuelto en la sentencia de vista, el contribuyente interpuso Recurso de Casación, el cual fue admitido y declarado procedente y finalmente resuelto. Entre las causales invocadas por el contribuyente, se alude a la falta de motivación de las resoluciones judiciales y afectación al debido proceso, alegando falta de motivación y motivación aparente en la pretensión principal al no existir motivación interna de razonamiento relacionado con las pretensiones principal. Respecto a la pretensión subordinada, dijo que la Sala en un único considerando alegó que la pretensión del demandante no fue solicitada oportunamente en el Tribunal Fiscal, por lo que era improcedente. La Corte Suprema, respecto a estos temas procesales, declaró infundado el recurso de casación, por considerar que la Sala Superior había motivado bien la sentencia de vista.

Así que pasó a analizar el tema de fondo, respecto a las causales de infracción normativa por la indebida aplicación del Artículo $86^{\circ}$ del TUO de la Ley General de Minería; interpretación errónea del cuarto párrafo del Artículo $83^{\circ}$ de la ley mencionada, así como del Artículo $22^{\circ}$ del Reglamento de Garantías de Estabilidad Minera; y finalmente la inaplicación indebida el Artículo $2^{\circ}$ de la Ley de Regalía Minera y el segundo párrafo del Artículo $8^{\circ}$ del TUO de la Ley General de Minería.

Tras hacer un análisis constitucional, analizar la naturaleza de los convenios de estabilidad, así como las disposiciones del TUO de la Ley General de Minería, la Corte Suprema se pronuncia sobre los agravios que denunció el contribuyente.

$\mathrm{Al}$ respecto sostiene que la sentencia de vista infringió el Artículo $86^{\circ}$ del TUO de la Ley General de Minería al sostener que el Convenio de Estabilidad Jurídica debe interpretarse exclusivamente a lo negociado, como si se tratase de un contrato civil, omitiendo la aplicación del mencionado artículo. Para el demandante, el Convenio de 
Estabilidad son contratos de adhesión de origen administrativo, el cual se vincula con la regulación contenida en el TUO de la Ley General de Minería. La Corte Suprema, interpreta que si bien es cierto que los Convenios de Estabilidad son contratos de adhesión, estos si se han interpretado en conjunto con la Ley General de Minería, por lo que no existiría infracción. Por otro lado, la Corte Suprema señala que el Estudio de Factibilidad Técnico-Económico califica no solo como requisito para acceder al convenio, sino que es el instrumento técnico necesario para evaluar y medir el grado de inversión. Por estos fundamentos, es que desestima dicho agravio.

Respecto a la infracción normativa del Artículo $83^{\circ}$ cuarto párrafo del TUO de la Ley General de Minería y el Artículo $22^{\circ}$ del Reglamento de la Ley General de Minería, interpreta que el beneficio contractual no recae sobre cualquiera de las actividades de la empresa minera, sino únicamente en las actividades que se derivan de la inversión realizada, es por ello que la ley usa el término "exclusivamente", lo cual excluye a cualquier otra actividad, y solo se fija en las actividades relacionales con la inversión prevista en el Estudio de factibilidad; es por ello que el Artículo $19^{\circ}$ del Reglamento de Garantías de Estabilidad Minera, exige el detalle de todas las obras a llevarse a cabo, maquinaria y equipo, plazo, cronograma, inversión desagregada, etc.

Asimismo, señala que la aprobación de la ampliación de la Planta de Beneficio de Cerro Verde no está vinculada al programa de inversión - Proyecto de Sulfuros Primarios, y no entra al Proyecto de Lixiviación de Cerro Verde que trata el Convenio de Estabilidad. Es por esa razón, que se desestima dicha infracción normativa.

Respecto al último agravio referente a la inaplicación indebida del Artículo $2^{\circ}$ de la Ley de Regalía Minera y el segundo párrafo del Artículo $8^{\circ}$ del TUO de la Ley General de Minería, la Corte Suprema sostuvo que esta fue aplicada con arreglo a ley, más aún si se tiene en cuenta que las inversiones de la Planta de Sulfuros Primarios no se encuentran estabilizadas. Es por ello, que este agravio fue desestimado.

Finalmente, respecto a este caso, tenemos que se declaró infundado el Recurso de Casación y se confirmó la sentencia de vista que declaró infundada la demanda.

\subsubsection{Nuestro análisis de la RTF 8252-1-2013 sobre el caso Cerro Verde.}

A efectos de analizar la problemática y fijar nuestra posición, primero tenemos que examinar cuales son las disposiciones que le son aplicables al contribuyente. El 
Convenio de Estabilidad del contribuyente fue celebrado el 13 de febrero de 1998, siendo su estabilidad por 15 años, conforme al Artículo $82^{\circ}$ del TUO de la Ley General de Minería vigente al momento de la aprobación del estudio de factibilidad, el cual fue aprobado por la Dirección General de Minería conforme al Artículo $85^{\circ}$ de la indicada norma.

En este punto debemos de precisar, que, además del TUO de la Ley General de Minería original, le es aplicable el Decreto Ley 26121 que modifica el segundo párrafo del Artículo $84^{\circ}$; no le es aplicable al régimen tributario estabilizado las disposiciones de la Ley 27341 que modifica el primer párrafo del Artículo 84 que reduce la depreciación de edificaciones y construcciones al máximo de 5\%, ni le son aplicables las leyes 27343 , 27909, ni demás modificaciones posteriores a la aprobación del estudio de factibilidad.

Ahora, respecto al problema, el contribuyente invirtió en la planta de Sulfuros Primarios en el año 2004, la suma de US\$ 800’030,000.00 (Ochocientos Millones Treinta Mil y 00/100 Dólares Americanos) el cual fue aprobado por Resolución Ministerial $N^{\circ}$ 510-2004-EM. Sin embargo, el problema se da, a partir del cuestionamiento de la Administración Tributaria, si esta inversión se encuentra estabilizada o no, y si esta forma parte de las inversiones del Proyecto de Lixiviación de Cerro Verde, el cual fue aprobado dentro del Convenio de Estabilidad suscrito con el contribuyente. A partir de ello, es que la Administración Tributaria pretende cobrarle las regalías mineras comprendidas en el periodo de enero a diciembre del 2008.

Antes de revisar el caso concreto, debemos tomar en cuenta que la estabilidad tributaria recogida en el Artículo $78^{\circ}$ y $82^{\circ}$ del TUO de la Ley General de Minería (aplicables al caso Cerro Verde), otorga estabilidad tributaria a los titulares de la actividad minera que inicien actividades o realicen ampliaciones para llegar a la capacidad exigida por ley.

En caso del Artículo 83 del TUO de la Ley General de Minería que le es aplicable al caso en concreto por tratarse de una estabilidad de 15 años, la redacción de dicho artículo señalaba claramente que: "el beneficio contractual recaerá exclusivamente en las actividades de la empresa minera en favor de la cual se efectúe la inversión”. Del referido texto, podemos revisar, que la norma es bastante precisa cuando menciona la frase "exclusivamente", por ello, que las actividades que sean ajenas a la inversión, no se encontrarán estabilizadas. 
El Artículo $85^{\circ}$ del TUO de la Ley General de Minería por su parte hace referencia que se debe de presentar un Estudio de factibilidad técnico-económico, para poder gozar del beneficio garantizado. El Artículo $19^{\circ}$ Reglamento de Garantías de Estabilidad Minera - Decreto Supremo $N^{\circ}$ 024-93-EM referente al estudio de factibilidad precisa en forma concreta, que debe de precisarse las obras a llevarse a cabo, debiendo detallarse inclusive las plantas de concentración.

El Artículo $20^{\circ}$ del Reglamento de Garantías de Estabilidad Minera, hace referencia que en el curso de la ejecución puede modificarse el estudio de factibilidad mientras no se afecte el objeto final del mismo, siempre que las apruebe la Dirección General de Minería. Por otro lado, el Artículo $22^{\circ}$ del mismo reglamento, señala que los beneficios al titular serán "exclusivamente por las inversiones que realice en las concesiones o Unidades Económico-Administrativas".

En ese sentido, nuestra posición, es que de acuerdo, al Artículo $20^{\circ}$ del Reglamento, la norma es bastante precisa, y se permiten modificaciones al estudio de factibilidad y por ende de la inversión estabilizada, mientras esté en ejecución el proyecto y no se afecte la finalidad del mismo.

En ese sentido, para nosotros está claro, que en lo que respecta al análisis normativo, la interpretación judicial y del Tribunal Fiscal es correcta, ya que lo estabilizado era la inversión, pudiendo realizarse ampliaciones o modificaciones del Estudio de Factibilidad, las cuales deberían de ser aprobadas por la autoridad minera.

Por otro lado, nuestra posición es que la Corte Suprema hizo un correcto análisis de cuál es la finalidad constitucional de los Convenios de Estabilidad, así como la finalidad del TUO de la Ley General de Minería, que más allá de buscar recaudación, lo que busca es inversiones para el desarrollo del país. En ese sentido, la Corte Suprema no podría interpretar de modo general el alcance del Artículo $83^{\circ}$ del TUO, y señalar que todas las inversiones no previstas en el estudio de factibilidad estarían estabilizadas, porque lamentablemente no es así, más aún si desde la solicitud queda claro que se busca estabilizar las inversiones a ejecutarse y el Estudio de Factibilidad es una herramienta, más que todo de control para la ejecución de la inversión, y si bien, basta para acreditar la inversión presentar una declaración jurada, refrendada por auditor externo conforme lo indica el Artículo $85^{\circ}$ de la Ley General de Minería, ello no restringe las acciones de control por parte de la autoridad minera, las cuales tiene conforme al Artículo $101^{\circ}$ literal 
e) y l) que prevén que la Dirección General de Minería vele por el cumplimiento de los contratos de estabilidad jurídica y que impongan multas y sanciones a los titulares de derechos mineros que incumplan con la Ley y el Reglamento.

Ahora con respecto al tema de fondo, analizaremos si se encuentra estabilizado o no, el proyecto de Sulfuros Primarios y si se encuentra dentro del Convenio de Estabilidad suscrito el 13 de febrero de 1998. De los hechos, queda en evidencia, que la Planta de Beneficio Cerro Verde fue terminada en ese mismo año, y su la culminación de su ejecución fue aprobada el 23 de noviembre de 1998, mediante Resolución Directoral $\mathrm{N}^{\circ}$ 342-98-EM/DGM; mientras que la autorización para la instalación de la planta de Sulfuros Primarios fue realizada el año 2004.

Considerando las normas legales arriba expuestas, así como las disposiciones reglamentarias, queda en evidencia que este proyecto de Sulfuros Primarios fue ejecutado varios años después de culminada la ejecución de la inversión estabilizada en el Convenio de Estabilidad de 1998, por ende, no podría considerarse como estabilizada.

En muchas partes en la defensa técnica del contribuyente ha dado a entender que la planta de Sulfuros Primarios forma parte del proyecto de lixiviación de Cerro Verde, sin embargo, esta afirmación no es correcta, ni condice con la naturaleza de lo que es una planta de lixiviación y lo que es una planta de sulfuros primarios, las cuales sirven para obtener cátodos de cobre con distintos grados de pureza entre sí, utilizando procesos químicos distintos.

Por otro lado, quisiéramos hacer referencia al Convenio de Estabilidad en sí mismo, tras leer las cláusulas primera, tercera, cuarta y quinta, queda bastante claro, que se ha estabilizado el monto de la inversión, quedando claro, que el monto definitivo se fija a la terminación de las obras. Por ende, nos parece plausible la explicación del Tribunal Fiscal y del Poder Judicial, en el sentido que la Planta de Sulfuros Primarios, cuya instalación fue solicitada en el 2004, no se encuentre incluida dentro de las inversiones estabilizadas por el Convenio de Estabilidad celebrado en 1998, ya que, para dicha oportunidad, las inversiones estabilizadas ya habían sido ejecutadas en su totalidad.

Asimismo, hay que añadir, que en el nuevo Convenio de estabilidad celebrado entre el contribuyente y el Estado Peruano, el año 2012, que tenía por objeto expandir las instalaciones para procesar mayores sulfuros lixiviables como no lixiviables, allí se 
encontraba una segunda planta de sulfuros, con lo cual nos da mayor certeza que la "Planta de Sulfuros Primarios" no estaba dentro de las inversiones estabilizadas.

Ahora, con relación al sentido económico de ello, consideramos que Cerro Verde no buscó suscribir un nuevo convenio de estabilidad con el Estado por la inversión ascendente a US\$ 800’030,000.00 (Ochocientos Millones Treinta Mil y 00/100 Dólares Americanos) que fueron invertidos para la Planta de Sulfuros Primarios, porque le serían de aplicación las normas del año 2004 y no las normas de 1998 que eran mucho más favorables a la inversión, dado a que en aquél entonces la depreciación de las edificaciones y construcciones tenía una tasa máxima de $20 \%$ anual (toda vez que se encontraba dentro del rubro de "demás activos fijos") en el Artículo $84^{\circ}$ del TUO de la Ley General de Minería, mientras que con la Ley 27341, la tasa bajó al límite máximo de $5 \%$ anual; igualmente hubiera tenido el inconveniente de tener que pagar el Impuesto a la Renta con la sobretasa de 2\% adicional por la aplicación de la Ley 27343; y además hubiera tenido el inconveniente de tener que asumir las demás obligaciones del ordenamiento jurídico, entre ellas las regalías mineras reclamadas por la Administración Tributaria en aplicación de la Ley 28258.

Finalmente, consideramos que el impacto económico no deseado por el contribuyente también tuvo un impacto negativo para el Estado en lo que respecta a los Convenios de Estabilidad en materia minera, no porque jurídicamente no le asista la razón al Estado, sino porque "mediáticamente", puede verse como una afectación a la estabilidad jurídica concedida por el ordenamiento jurídico por personas ajenas al quehacer jurídico y que no conozcan los detalles del caso.

\subsection{Del impacto del Caso Cerro Verde en nuestra legislación con las Leyes 30230 y 30296, que buscan que las inversiones adicionales formen parte del régimen tributario estabilizado.}

\subsubsection{Situación de las inversiones adicionales antes de las leyes 30230 y 30296 .}

De nuestra investigación, hemos advertido que antes del caso Cerro Verde, los contribuyentes tenían dos formas de acceder a los Convenios de Estabilidad, ya sea a iniciando actividades o realizando operaciones que les permitan llegar a la capacidad exigida por la norma (es decir ampliar sus actividades), conforme se puede advertir de los Artículos $78^{\circ}, 79^{\circ}$ y $82^{\circ}$ y $83^{\circ}$ del TUO de la Ley General de Minería antes de su 
modificación por las leyes 30230 y 30296. De la relación de Contratos de Garantías y Promoción de la Inversión publicados por el propio Ministerio de Energía y Minas (Ministerio de Energía y Minas), la práctica regular de los contribuyentes ha sido no solo estabilizar sus inversiones iniciales, sino también han buscado estabilizar las inversiones adicionales a través de los Convenios de Estabilidad correspondientes, como lo hizo en su momento el propio Cerro Verde en su convenio de estabilidad tributaria del 13 de febrero de 1998, Santa Luisa en su convenio de estabilidad tributaria del 25 de septiembre de 1998, MILPO en su convenio de estabilidad del 27 de noviembre de 2002.

Un caso distinto, es el del proyecto Las Bambas, este fue suscrito el 20 de julio del 2011, dado a que tuvo problemas en su ejecución suscribió dos adendas, una el 20 de noviembre del 2014, modificando el monto de la inversión, el contenido de la inversión y el plazo, hecho que igualmente ocurrió el 18 de mayo del 2016. En este caso, consideramos que se cumplió lo previsto en el Artículo $20^{\circ}$ del Reglamento de Garantías de Estabilidad Minera - Decreto Supremo $N^{\circ}$ 024-93-EM, que previa que podría modificarse el estudio de factibilidad una o más veces en el curso de su ejecución, ello en razón a que el contribuyente pidió a la Dirección General de Minería modificar los plazos y otras condiciones, lo cual finalmente le fue aceptado por resolución directoral y ello se plasmó en las adendas contractuales correspondientes.

\subsubsection{De la Ley 30230 que amplió la estabilidad tributaria en minería a las inversiones adicionales}

La Ley 30230 fue publicada el 12 de junio del 2014 y no tiene exposición de motivos, sin embargo, en el diario de debates del Congreso de la República de fecha 03 de julio del 2014 (Ministerio de Justicia, 2019), en la Comisión Permanente se expuso de forma muy sucinta que el objetivo de dicha norma gira en torno a tres grandes ejes:

"Fortalecer la seguridad jurídica a los contribuyentes.

Reducción y dar mayor predictibilidad de costos para el sector privado.

Complementar el proceso de toma de decisiones con racionalidad económica" 
Respecto a los convenios de estabilidad tributaria en el sector minero, se señala en el Diario de Debates referido, que se buscaba “ampliar la estabilidad tributaria a las inversiones adicionales en minería, ya que con el marco legal vigente no cabe estabilizar aquellas inversiones que no constan en estudios de factibilidad que se adjunta a los contratos de estabilidad tributaria".

Para culminar, el análisis concerniente al citado Diario de debates no hay mayores aportes que puedan dar luces sobre lo que realmente quiso hacer el legislador, salvo discusiones en tornó al favorecimiento de la gran minería y otros temas políticos que no son objeto de la presente tesis.

Ahora pasaremos a analizar lo que hizo la Ley 30230. Esta norma además de eliminar la capitalización aplicable desde el 31 de diciembre de 1998 al 31 de diciembre del 2005, para deudas pendientes de pago, independientemente de que se encuentren en cobranza, reclamación, o apelación en el Tribunal Fiscal, lo cual nos parece cuestionable, ya que en lugar de hacer una modificación al Artículo $33^{\circ}$ del TUO del Código Tributario lo cual sería más lógico y hacer una norma más justa siguiendo los parámetros que ha ido estableciendo el Tribunal Constitucional sobre la aplicación del principio de proporcionalidad, prefirió enfocarse en dar soluciones temporales para determinados contribuyentes. Sin embargo, dado a que la presente tesis no es sobre la capitalización de intereses moratorios, continuaremos con las demás modificaciones que hizo sobre el tema que nos ocupa.

Esta norma modifica los artículos $79^{\circ}, 82$, el primero segundo y tercer párrafo del artículo $83^{\circ}$, el primer párrafo del Artículo $85^{\circ}$, el artículo $86^{\circ}$ y el inciso c) del Artículo $101^{\circ}$ del TUO de la Ley General de Minería, e incorpora los Artículos 83-A y 83-B del TUO de la Ley General de Minería.

En forma sencilla, esta norma modificó la forma en que se venía aplicando la estabilidad tributaria, lo cual generó que existan tres regímenes, uno de 10 años, el de 12 años y el de 15 años.

El problema con esta norma es que incrementó la inversión mínima en los convenios de estabilidad de 10 años previstos en el Artículo $79^{\circ}$ hasta US\$ 
20’000,000.00. Si bien puede un monto mínimo para el sector minero, tras revisar los convenios de estabilidad publicados por el Ministerio de Energía y Minas (Ministerio de Energía y Minas), hemos advertido que no existió ningún convenio de 10 años, en que se haya comprometido una inversión que sea igual o mayor a la suma de US\$20’000,000.00, siendo la mayor inversión realizada dentro de este régimen, una ampliación de mina por US\$ 14’162,600.00 conforme se puede ver del contrato de Compañía Minera Milpo S.A.A. del 27 de noviembre del 2002. En ese sentido, el monto indicado, no obedeció a un criterio técnico.

Otro inconveniente se genera cuando se modifica el artículo $82^{\circ}$ del TUO de la Ley General de Minería la cual originalmente estaba prevista para la estabilidad tributaria de $\underline{15}$ años y se modifica para que sea una estabilidad de $\underline{12}$ años, , sin embargo, si bien el texto mantiene lo referente al requisito sobre que los proyectos mineros tengan capacidad inicial no menor de 5,000 TM/día o de ampliaciones destinadas a llegar a una capacidad no menor de 5,000 TM/día, comete un error grave al referirse únicamente a la concesión minera y no a las unidades económicas administrativas, lo cual restringe los alcances de la norma a una sola concesión que tenga esa capacidad de producción, ya que muchos proyectos mineros se realizan por unidades económico administrativas, conforme se ha podido verificar de los propios contratos publicados por el Ministerio de Energía y Minas. Para poder visualizar mejor los cambios, reproduciremos el párrafo original y el párrafo modificado.

\begin{tabular}{|l|l|}
\hline Antes de Ley 30230 & Después de la Ley 30230 \\
\hline Artículo 82.- A fin de promover la inversión y facilitar el & Artículo 82.- A fin de promover la inversión y facilitar el \\
financiamiento de los proyectos mineros con capacidad & financiamiento de los proyectos mineros con capacidad \\
inicial no menor de 5,000 TM/día o de ampliaciones & inicial no menor de 5,000 TM/día o de ampliaciones \\
destinadas a llegar a una capacidad no menor de 5,000 & destinadas a llegar a una capacidad no menor de 5,000 \\
TM/día referentes a una o más Unidades Económicas & TM/día referentes a la concesión minera, los titulares de \\
Administrativas, los titulares de la actividad minera & la actividad minera gozarán de estabilidad tributaria que se \\
\hline gozarán de estabilidad tributaria que se les garantizará & les garantizará mediante contrato suscrito con el Estado, \\
mediante contrato suscrito con el Estado, por un plazo de & por un plazo de doce años, contados a partir del ejercicio \\
quince años, contados a partir del ejercicio en que se & en que se acredite la ejecución de la inversión o de la \\
acredite la ejecución de la inversión o de la ampliación, & ampliación, según sea el caso.” \\
según sea el caso. & \\
\hline
\end{tabular}

El Artículo $83^{\circ}$ del TUO de la Ley General de Minería, también es modificado, e incrementa la inversión inicial requerida, pasando de US\$20’000,000.00 a US\$ 
100’000,000.00; y para las empresas existentes se incrementó el monto de la inversión pasando de US\$ 50'000,000.00 a US\$250'000,000.00. Como no hay antecedentes de contratos de estabilidad tributaria de 12 años en el sector minero, no hay más comparables, que los contratos de 15 años, si analizamos los convenios de estabilidad desde el 2004 hasta diciembre del 2013, el monto más pequeño de inversión ha sido de US\$261'834,000.00, que corresponde al proyecto de Alto Chicama conforme se aprecia del convenio que suscribió con el Estado el 29 de diciembre del 2004, por lo que los montos mínimos de inversión exigidos no resultan fuera de lugar.

Otro artículo que fue modificado por la Ley 30230, fue el Artículo $85^{\circ}$ del TUO de la Ley General de Minería, precisando que los titulares de la actividad minera, comprendidos en los alcances de los artículos 82, 83, 83-A y 83-B, para acceder a los beneficios garantizados deben de presentar un estudio de factibilidad técnico-económico; el resto de la redacción siguió tal como fue redactado en el texto original de dicho artículo.

Este artículo modificado, claramente buscaba que se cumpla con la condición del estudio de factibilidad para los convenios de 12 y 15 años, pero sin pretenderlo, generaron un nuevo problema y terminaron dejando sin efecto parcialmente la Ley 27343, que establecía que la garantía de estabilidad estabilizaba los impuestos vigentes no siendo de aplicación los que se creen con posterioridad a la suscripción del contrato correspondiente y también la referente a que la estabilidad del Impuesto a la Renta era la que correspondía aplicar de acuerdo a las normas vigentes al momento de la suscripción del contrato correspondiente. En ese sentido, este error, volvió a establecer, que la estabilidad tributaria de 12 y 15 años se rigiera por la fecha de aprobación de la fecha del estudio de factibilidad, ya sea en forma expresa o ficta.

Otra modificación fue la del Artículo $86^{\circ}$ del TUO de la Ley General de Minería, que precisó que los nuevos modelos de convenios de 12 y 15 años sean aprobados por Decreto Supremo.

El cambio legislativo más importante de la Ley 30230, fue el nuevo régimen tributario para la estabilidad de 15 años, al incorporar los Artículos 83-A y 83-B a la Ley General de Minería. Para poder visualizarlo mejor, analicemos el siguiente recuadro:

\section{\begin{tabular}{l|l} 
Artículo (Nuevo régimen de 15 años) & Requisitos
\end{tabular}}




\begin{tabular}{|c|c|}
\hline 83-A & $\begin{array}{l}\text { Capacidad inicial } \geq 15,000 \mathrm{TM} / \text { día } \\
\text { Ampliaciones } \geq 20,000 \mathrm{TM} / \text { día } \\
\text { - Aplica para una concesión minera. }\end{array}$ \\
\hline \multirow[t]{2}{*}{ 83-B } & $\begin{array}{l}\text { Inversión inicial o ampliaciones } \\
\geq \text { US } \$ 500 \text { millones. } \\
\text { - Por excepción se incluye a } \\
\text { personas que inviertan en las } \\
\text { empresas que conforman la } \\
\text { actividad empresarial del Estado } \\
\text { sujetas al proceso de privatización. }\end{array}$ \\
\hline & $\begin{array}{l}\text { Para inversiones adicionales posteriores } \\
\text { a la culminación del programa de } \\
\text { inversiones se exige: } \\
\text { - Se realicen en la misma } \\
\text { concesión donde se desarrolle el } \\
\text { programa de inversión. } \\
\text { - } \geqslant \text { US\$ } 250 \text { '000,000.00 } \\
\text { - Se apruebe previamente por el } \\
\text { Ministerio de Energía y Minas } \\
\text { - No se suma plazo adicional a la } \\
\text { estabilidad garantizada. }\end{array}$ \\
\hline
\end{tabular}

Conforme se puede advertir, el Artículo 82-A cometió para empezar el mismo error que en la estabilidad de 12 años, exigir una capacidad para estabilizar una concesión, en lugar de señalar que la capacidad exigida estaba referida a una o más concesiones o Unidades Económicas Administrativas, lo cual sería lo más razonable.

Otro aspecto relevante, del Artículo 82-A, es como se pasó de exigir una capacidad inicial de 5,000 TM/día a 15,000 TM/día, sin ningún tipo de sustento técnico que lo respalde. Por otro lado, las ampliaciones se extendieron de 5,000 TM/día a 20,000 TM/ día. Nuestra opinión, es que el legislador debió de considerar por lo menos, la producción diaria en los convenios de estabilidad minera suscritos con el estado. 
En el Artículo 83-B se exigió una suma mayor o igual a US\$ 500’000,000.00, suma que consideramos debería de ser más baja, a efectos de captar la mayor cantidad de inversiones posible. Líneas arriba, hemos mencionado, que desde el 2004 hasta diciembre del 2013, el monto más pequeño de inversión por una estabilidad de 15 años, ha sido de US\$ $261^{\prime} 834,000.00$, que corresponde al proyecto de Alto Chicama conforme se aprecia del convenio que suscribió con el Estado el 29 de diciembre del 2004, por lo que podría trabajarse en el monto para llevarlo a una suma más "realista".

El Artículo 83-B incorpora como novedad, las inversiones adicionales posteriores a la ejecución de la inversión. En este caso, se exige como inversión adicional que lo menos se invierta US\$ 250’000,000.00 pero cometiendo el mismo error que en las demás modificaciones de la Ley 30230, las restringe a una concesión.

Asimismo, estas inversiones deben estar vinculadas al proyecto de inversión original y deben ser aprobadas por el Ministerio de Energía y Minas. Si recapitulamos el caso Cerro Verde, tanto el Tribunal Fiscal como el Poder Judicial determinaron que una Planta de sulfuros no era lo mismo que una Planta de Lixiviación, con ello podemos concluir, que no se podría solucionar un caso similar al de Cerro Verde con la Ley 30230.

Con relación al monto, consideramos que el requisito de inversión adicional es demasiado oneroso para tratarse de una ampliación posterior a la ejecución del programa de inversiones, y que no va a extender la estabilidad.

Otra modificación, un poco menos importante es la modificación del Artículo $101^{\circ}$ literal c) del TUO de la Ley General de Minería, que reguló que la Dirección General de Minería sea quien apruebe los estudios de factibilidad.

Finalmente, a efectos de concluir el análisis de la Ley 30230, debemos de señalar que los problemas de dicha norma, no solo concluyen con lo que se ha expresado en ella, sino con lo que no hizo; así encontramos, que la Ley 30230 al modificar el TUO de la Ley General de Minería omitió modificar el Artículo $84^{\circ}$ a efectos de expresar en esa norma las modificaciones a la estabilidad de 12 y 15 años, así tenemos que solo hay depreciación acelerada en la concesión de 15 años y no la de 12 años, además encontramos que la contabilidad en moneda extranjera le fue otorgada a la estabilidad de 12 años (ello porque la norma se refiere al Artículo $82^{\circ}$ modificado) en lugar del Convenio de 
estabilidad tributaria de 15 años, aspecto que resulta en un daño no deseado por el legislador.

\subsubsection{De la Ley 30296 que buscó corregir los errores de la Ley 30230.}

La Ley 30296 se publicó el 31 de diciembre del 2014, en ella se modificó el

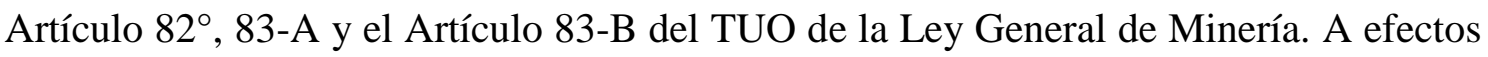
de poder revisar cual había sido la real voluntad del legislador al implementar la mencionada norma, es que se analizó el Dictamen del proyecto 4007/2004-PE (Congreso de la República, 2019), y no se encontró mayor análisis en todo el documento, salvo que en el análisis costo beneficio en el punto VI, en el que se concluye que "no representa costo alguno para el Tesoro Público.", lo cual evidentemente no es cierto, ya que toda decisión legislativa tiene impacto económico. En el Dictamen en minoría, si se desarrolla más el proyecto de ley, en lo que respecta al tema que nos ocupa, y manifiesta su desacuerdo a la reducción a que las inversiones adicionales sean reducidas a la suma de US\$ 25’000,000.00, también se cuestiona la definición de UEA que se incorpora en el proyecto de ley, debido al carácter extenso que tiene.

Teniendo en consideración lo expuesto, pasaremos a revisar las cuestiones normativas. En la Ley 30296 aprobada a pocos meses de la Ley 30230, se realizaron cambios importantes en los artículos 82-A y 83-B del TUO de la Ley General de Minería.

El primer párrafo del Artículo 82-A fue modificado a efectos de que la capacidad inicial y ampliaciones para acceder a la estabilidad de 12 años, sean no menores a las 5,000 TM/día, para una o más concesiones, o a una o más Unidades Económicas Administras, con ello se corrigió el error de la Ley 30230.

El segundo párrafo del Artículo 82-A modificado nos llamó la atención dado que señala:

"Para los efectos de los contratos a que se refieren los artículos 78, 83-A y el presente artículo, se entiende por Unidad Económica Administrativa, el conjunto de concesiones mineras ubicadas dentro de los límites señalados por el artículo 44 de la presente Ley, las plantas de beneficio y los demás bienes que constituyan una sola unidad de producción por razón de comunidad de abastecimiento, administración y servicios que, en cada caso, calificará la Dirección General de Minería”.

Tal como esta expresado esta norma, aplica a los convenios de estabilidad de 10, 12 y 15 años. Lo extraño de esta modificación, es ¿por qué no se modificó el Artículo $44^{\circ}$ 
del TUO de la Ley General de Minería si es que quería el legislador modificar la definición de Unidad Económica Administrativa? En primera instancia podríamos señalar que fue por mala técnica legislativa, pero si analizamos un poco más el tema, podríamos señalar que ello fue para que esta definición solo alcance a las empresas mineras que tengan Convenio de Estabilidad de 10, 12 y 15 años.

El Artículo $44^{\circ}$ del TUO de la Ley General de Minería, sirve para agrupar concesiones mineras de la misma clase siempre y cuando estén ubicadas dentro de los límites señalados en el referido artículo. En este caso, volviendo a lo especificado en puntos atrás, tenemos que hay diferentes tipos de concesiones en el TUO de la Ley General de Minería, entre ellas las concesiones mineras, de beneficio, de labor general y de transporte minero; al hacer la modificación del Artículo 82 respecto a la definición de UEA, se ha querido permitir que concesiones diferentes a la concesión minera entren a formar parte de la UEA, a fin de llegar a la capacidad exigida por la norma, incluyendo las plantas de beneficio y demás bienes que sean una sola unidad de producción por razón de comunidad, abastecimiento, administración y servicios que calificará la Dirección General de Minería. Desde nuestra perspectiva, se está buscando incluso superar las expectativas del caso Cerro Verde, ya que se está incorporando otra clase de bienes ajenos a la actividad productiva, cuando se refiere a "demás bienes que sean una sola unidad de producción por razón de comunidad, abastecimiento, administración y servicios", lo cual es ya un exceso, ya que al ser tan genérica podría abarcar bienes ajenos a la producción minera, es por ello, que somos de la opinión que dicho párrafo debe ser modificado y ser preciso respecto a sus alcances.

La modificación del Artículo 83-A que hace la Ley 30296 es idéntica a lo antes expuesto respecto al primer párrafo del Artículo 82 del TUO de la Ley General de Minería, ya que se refiera que la capacidad inicial y ampliaciones, estarán referidas a una o más concesiones o a una o más Unidades Económicas Administrativas. Respecto a esto, reiteramos nuestros comentarios realizados en párrafos anteriores.

Finalmente, se modifica el tercer párrafo del artículo 83-B del Texto Único Ordenado de la Ley General de Minería, este párrafo es importante, ya que reduce las inversiones adicionales de US\$ 250’000,000.00 a US\$25’000,000.00. Respecto a ello, nos parece razonable su reducción, considerando que no añaden plazo adicional a la estabilidad, ni sirven para el cómputo de un nuevo plazo. 
En este punto, podemos hacer una crítica, por cuanto la Ley 30296 corrige los errores de la Ley 30230, referentes a la falta de modificación del Artículo $84^{\circ}$ a efectos de modificar la depreciación acelerada a efectos de añadir la estabilidad de 12 años, además encontramos que no se corrigió que la contabilidad en moneda extranjera que le fue otorgada a la estabilidad de 12 años sea devuelta a la estabilidad de 15 años.

\subsection{Otros problemas para las inversiones mineras estabilizadas. La determinación del Impuesto a la Renta.}

Precisamos que las cuestionables modificaciones hechas por las Leyes $30230 \mathrm{y}$ 30296 al TUO de la Ley General de Minería que han sido mencionadas en los puntos anteriores, no son los únicos problemas que tienen las inversiones mineras con estabilidad tributaria; ya que tenemos que el TUO de la Ley General de Minería no ha procedido a dar un a normatividad clara y coherente que ayude a los inversionistas a determinar su impuesto a la renta en caso tenga diferentes tipos de concesiones (con estabilidad y sin estabilidad) o actividades, lo cual puede llevar.

En este punto nos referiremos al Artículo $22^{\circ}$ del Reglamento de Garantías y Medidas de Promoción a la Inversión en la actividad minera, que señala en su segundo párrafo lo siguiente:

"Para determinar los resultados de sus operaciones el titular de actividad minera que tuviera otras concesiones o Unidades Económico - Administrativas deberá llevar cuentas independientes y reflejarlas en resultados separados."

Como observamos de la norma citada no está definido como se debe realizar la determinación del Impuesto a la Renta, solo nos indica que deben llevar cuentas independientes y reflejarlas en resultados separados. Tomando en consideración dicha situación, ¿cuál sería la mejor forma de determinar el cálculo si la empresa tiene dos o más UEA o concesiones a su cargo? ¿Qué pasa si la empresa tiene concesiones no estabilizadas? o ¿Qué pasaría si la empresa tiene actividades de negocios afines y tiene perdidas?

Recordemos en este punto que la estabilización que ofrece los convenios es para inversión que se realice en una UEA o una concesión no estabiliza la empresa, entonces ¿cómo se deberá determinar el cálculo en cada una de las hipótesis?, si es que no está establecida en la ley, y considerando está regulada en forma inadecuada en el reglamento. 
Para eso desarrollaremos un ejemplo, supongamos que la empresa $\mathrm{ABC}$ tiene tres concesiones (A, B y C) con tasas del impuesto a la renta diferentes $(28 \%, 30 \%$ y $29.5 \%$ respectivamente), dos concesiones tienen utilidad y una tiene perdida:

\begin{tabular}{|l|l|l|l|}
\hline Empresa ABC & Actividad A & Actividad B & Actividad C \\
\hline Tasa & $28 \%$ & $30 \%$ & $29.5 \%$ \\
\hline Resultado & Utilidad & Utilidad & Perdida \\
\hline $\begin{array}{l}\text { Resultado antes de } \\
\text { impuestos }\end{array}$ & 100,000 & 100,000 & $-20,000(*)$ \\
\hline $\begin{array}{l}\text { Nuevo cálculo } \\
\text { Impuesto a } \quad \text { la }\end{array}$ & 28,000 & $-20,000$ & \\
\hline Renta & & 80,000 & \\
\hline Total a pagar & & 24,000 & \\
\hline
\end{tabular}

En principio como se puede observar del recuadro anterior, se está cumpliendo con el reglamento, es decir se lleva la contabilidad respecto a cada concesión estabilizada, así como las actividades sin estabilizar en resultados separados, para luego simplemente determinar el impuesto a la renta que correspondería pagar a cada uno de esos resultados, siendo la suma de todos ellos el importe a pagar por la persona jurídica. Para llegar a esto se tomó en consideración lo expresado en la RTF ํㅜ 20290-1-2011, sin embargo esta no es de observancia obligatoria, y si bien existe el Informe N$^{\circ}$ 084-2012-SUNAT/4B0000, consideramos que ello no es suficiente, ya que efectos de respetar el principio de legalidad recogido en el Artículo $74^{\circ}$ de la Constitución del Estado, esto debe estar contemplado en forma clara y precisa en el TUO de la Ley General de Minería, como si sucede en el sector hidrocarburos, en el Artículo $50^{\circ}$ del TUO de la Ley de Hidrocarburos - Decreto Supremo N 042-2005-EM, en el cual sí queda claro cómo debe determinarse el impuesto, y como se aplican las pérdidas a los resultados de cada una de los contratos o actividades del contratista. 


\section{Capitulo III: Planteamientos para mejorar la estabilidad de las inversiones en el sector minero.}

3.1.La confianza legitima y buena fe en la interpretación de la normatividad estabilizada.

No hay lugar a dudas que regular los Convenios de Estabilidad, a satisfacción tanto del sector privado como del Estado, no es un asunto sencillo, y la búsqueda de una relación ganar-ganar para ambas partes siempre es perfectible, esto debe de realizarse, no solo para que los inversionistas obtengan un provecho económico legitimo en su actividad 
con normas claras y previsibles; sino para que el Estado pueda atraer al país las inversiones y recursos para lograr buscar el bienestar general conforme a lo previsto en el Artículo $44^{\circ}$ de la Constitución. Para llegar a este camino, se ha tenido que pasar por diversas etapas.

En el pasado estuvieron vigentes los Decretos Leyes 22774 y 22775, que regulaban la celebración de contratos de exploración y/o explotación de hidrocarburos, entre Petroperú y los particulares. De acuerdo a esta normatividad, los hidrocarburos eran de propiedad del Estado y los hidrocarburos propiedad de Petroperú, y lo único que celebraba dicha empresa era que pueda celebrar contratos con los particulares con la finalidad de extraer los hidrocarburos que se descubran en el área del contrato. De acuerdo con estas normas, solo existían contratos de servicios, en los cuales el riesgo podría ser asumido solo por el contratista o en forma compartida entre el contratista y Petroperú.

Cabe recalcar que estas normas se dieron durante el régimen militar del General Francisco Morales Bermúdez, así que hay que entender dichas normas dentro de su contexto histórico, es por eso, que al revisarlas vemos que eran muy restrictivas en cuanto a la participación del sector privado en la exploración y explotación de los hidrocarburos, fijando disposiciones, como por el caso previsto en el 6.2, respecto a las formas de pago de la retribución, las cuales si bien podrían ser en dinero o en especie, el Estado podría decidir que en caso pague en dinero y no se haya cumplido con el pago de tributos en forma oportuna, éste tenía la facultad de cobrar en especie, y asimismo, si pagaba en especie, era deber del contratista venderle primero a Petroperú y el exceso, recién podría ser exportado. Como se puede advertir a lo largo de ambas normas, el Estado buscaba imponer obligaciones a los contratistas, priorizando el interés nacional y el abastecimiento nacional, aplicando disposiciones que, en tiempos actuales, podrían considerarse poco serias. Sin embargo, entre los aspectos resaltantes de estas normas, tenemos por ejemplo el numeral 7.5 del Decreto Ley 22774, mediante el cual se los resultados de cada lote y/o actividad se determinarán en forma independiente y se consolidarán para efectos del cálculo del impuesto a la renta. Por otro lado, en este tipo de contratación, la contabilidad se llevaba conforme a la contabilidad de Perú y normas y prácticas nacionales, es decir, no se permitía llevar la contabilidad en moneda extranjera. Un punto más importante, en el Decreto Ley 22774 es que el Estado no otorgaba estabilidad tributaria a los contratistas, pero si podía garantizar que no les apliquen nuevos 
impuestos que graven específicamente a la actividad minera. Asimismo, no había una libre disponibilidad de divisas, estando obligado el contratista a entregar al Banco Central de Reserva, la totalidad de moneda extranjera que provenga de las ventas de exportación de hidrocarburos que le correspondan por su retribución en especie; y el Banco Central de Reserva podría liberar estas divisas cumpliendo una serie de requisitos conforme lo previsto en el numeral 8.5 de la Ley 22774. Por ley 24782, recién se incorporó el numeral 8.6 que garantizaba al contratista la disponibilidad de divisas, lo cual debería de estar acordado por el contrato. Finalmente, el contratista para suscribir un contrato con el Estado, debía de renunciar a su jurisdicción y someterse a la jurisdicción de Perú, no pudiendo realizar ningún reclamo diplomático. El Decreto Ley $\mathrm{N}^{\circ} 22775$, establecía el régimen tributario sectorial de Impuesto a la Renta, para las empresas contratistas que celebren contratos con el Estado, siendo el objeto principal de dicha norma, fortalecer no la estabilidad a favor del contratista, sino a Petro Perú. Esta norma regulaba, todo lo referente a los pagos a cuenta, deducciones al impuesto a la renta y amortización de los costos.

Siguiendo la cronología, consideramos que el Estado recién se tomó en serio, lo de la búsqueda de inversiones y el respeto a Convenios de Estabilidad con los Decretos Legislativos 662 y 757. El Decreto Legislativo 662, norma publicada el 02 de septiembre de 1991, básicamente buscó promover y garantizar las inversiones extranjeras, así como las empresas existentes o que se constituyan y que reciban aportes de capitales extranjeros.

Por otro lado, el Decreto Legislativo 757, publicada el 13 de noviembre de 1991, busca garantizar la libre iniciativa e inversiones privadas, y extiende las garantías a inversionistas nacionales, así como las empresas receptoras de la inversión, pudiendo estás últimas celebrar tales convenios conforme al Artículo $40^{\circ}$ de dicha norma. En el ámbito sectorial se aprobó el TUO de la Ley General de Minería - Decreto Supremo 01492-EM y el TUO de la Ley Orgánica de Hidrocarburos - Decreto Supremo Nº42-2005$\mathrm{EM}$, las cuales otorgaban convenios de estabilidad a las inversiones mineras y a los contratos en el sector de hidrocarburos celebrados con Perú Petro.

Ahora, siguiendo con este punto, sobre la ruta de los Convenios de Estabilidad, encontramos que la Ley 27342 del 06 de septiembre del 2000 por su parte estableció los requisitos mínimos de inversión para poder acceder al régimen de los Decretos 
Legislativos 662 y 757, y por otro lado, tal como ocurrió en el régimen sectorial con la Ley 27343, procedió a aumentar la tasa del Impuesto a la Renta a quienes suscribieran dicho convenios en dos puntos porcentuales, para darles la estabilidad vigente al momento de celebración del contrato, sin embargo ello quedó sin efecto rápidamente por la Ley 27514 del 28 de agosto del 2001.

Por otro lado, el Decreto Supremo No 162-92-EF - Reglamento de los Regímenes de Garantía a la Inversión Privada, fija con mayor detalle los alcances de las garantías para los inversionistas nacionales o extranjeros y las empresas receptoras de inversión.

Respecto a la caustica, debemos tomar en consideración, que la aplicación de los Convenios de Estabilidad no ha sido pacífica, en ese sentido hemos visto demandas de inconstitucionalidad, como el ocurrido en el caso del contrato suscrito con Telefónica, conforme se evidencia de la sentencia expedida por el Tribunal Constitucional $\mathrm{N}^{\circ} 0005$ 2003-AI, en la que felizmente, la referida instancia, señaló que la celebración del referido Convenio de Estabilidad tenía un fin legítimo, en cumplimiento del Artículo $44^{\circ}$ de la Constitución, esto es que el Estado cumpla con buscar el bienestar general a través de la promoción de la inversión.

Otro caso emblemático, que tenemos es el caso de Duke Energy, en la cual se cuestionó al Estado por desconocer la depreciación resultante de la reorganización empresarial de Egenor. En este caso, tenemos que por Decreto Legislativo 782, se había otorgado a las entidades estatales el derecho de reorganizarse sin que ello, tuviera una repercusión fiscal. El día 10 de enero de 1994, la Ley 26283 había dispuesto que se exonerará de impuesto a la renta, los actos consistentes en reorganizaciones empresariales hasta el 31 de diciembre de 1994, extendiéndose mediante normas posteriores el beneficio hasta el periodo anual de 1998. Por Decreto Supremo N 120-94-EF se reglamentó la Ley 26283. Por Ley 27034, el Congreso dispuso que las empresas que habían revaluado sus activos como consecuencia de la reorganización empresarial, ya no podrían seguir gozando de la depreciación una vez transcurrido el ejercicio de 1998. Entre 1995 y mayo de 1996, Electroperú se reorganizó y transfirió sus activos fijos (8 plantas eléctricas a Edelnor), habiéndose revaluado su valor. Electroperú aplicó las tasas de depreciación a los activos fijos de Egenor, habiendo recibido autorización de SUNAT para aplicar tasas de depreciación desaceleradas de la Resolución de Comisión de Tarifas Eléctricas $\mathrm{N}^{\circ}$ 013-87P/CTE del 30 de abril de 1987 a partir de 1996. 
Cuando se privatizó en 1996, Egenor, no se precisó la tasa de depreciación desacelerada, ni cual debería de aplicarse a Egenor después de la privatización, así que después de ello, la accionista de Egenor procedió a usar la depreciación desacelerada prevista para su anterior accionista Electroperú. Sin embargo, la Administración Tributaria procedió a desconocer la depreciación desacelerada y a pretender el pago de impuesto a la Renta. Es por ello, que al final terminó emitiéndose el Laudo Arbitral del Caso República del Perú con Duke Energy, que consideró que las interpretaciones existentes al momento de la celebración del convenio estaban incluidas en la estabilidad tributaria. En el referido Laudo se indicó en el punto 219, que: "En sentido amplio, la estabilidad es el estándar por el cual el ordenamiento jurídico predominante a la fecha que se otorgó la garantía se perpetúa, incluyendo la interpretación consistente y estable vigente al momento en que se suscribió el CEJ (Convenio de Estabilidad Jurídica. El Tribunal se encuentra convencido de que el mantenimiento de esas interpretaciones de la ley existentes al momento de la celebración del CEJ es parte de las reglas establecidas".

Respecto a ello, estamos de acuerdo con lo resuelto por el laudo arbitral, ya que al privatizarse Egenor, había una confianza legítima respecto a la depreciación de los activos fijos de la empresa privatizada, y no podría inaplicarse de forma alguna esta depreciación desacelerada.

En esas circunstancias, a efectos de proponer estabilidad tributaria en el sector minero y que exista buena fe o confianza legitima por parte del inversionista, consideramos que a efectos de brindar una estabilidad de ese tipo podría modificarse el literal a) del Artículo $80^{\circ}$ del TUO de la Ley General de Minería, a efectos de incluir dentro de la estabilidad los precedentes de observancia obligatoria del Tribunal Fiscal respecto a las normas estabilizadas y los informes de la Administración Tributaria en cuanto interpreten la aplicación de normas estabilizadas.

3.2.Sobre la posibilidad de aplicar disposiciones de los Decretos Legislativos 662 y 774 y las normas tributarias del TUO de la Ley Orgánica de Hidrocarburos al sector minero.

\subsubsection{De los beneficios del Decreto Legislativo 662 y 757.}

En el Decreto Legislativo 662 publicado el 02 de septiembre de 1991, se buscó promover y garantizar las inversiones extranjeras, así como las empresas existentes o que 
se constituyan y que reciban aportes de capitales extranjeros. Por otro lado, el Decreto Legislativo 757, publicada el 13 de noviembre de 1991, buscó garantizar la libre iniciativa e inversiones privadas, y extiende las garantías a inversionistas nacionales, así como las empresas receptoras de la inversión, pudiendo estás últimas celebrar tales convenios conforme al Artículo $40^{\circ}$ de dicha norma. Ambas normas fueron reglamentadas por el Decreto Supremo No 162-92-EF - Reglamento de los Regímenes de Garantía a la Inversión Privada, fija con mayor detalle los alcances de las garantías para los inversionistas nacionales o extranjeros y las empresas receptoras de inversión. Tal como se mencionó la Ley 27342 del 06 de septiembre del 2000 establece los requisitos de inversión para poder acceder al régimen de los Decretos Legislativos 662 y 757.

Los Convenios de Estabilidad de los Decretos Legislativos 662 y 757, regulan dos formas de estabilidad, para el inversionista y para la empresa receptora de la inversión.

En lo que respecta a la estabilidad a favor del inversionista, está protege fundamentalmente el derecho del inversionista al impuesto a la renta que sea de su cargo, así como al retorno de sus dividendos. En ese sentido encontramos que el Artículo $10^{\circ}$ inciso a) del Decreto Legislativo 662, el cual respecto a la estabilidad tributaria que otorga al inversionista precisa que se garantiza, al inversionista extranjero respecto al impuesto a la renta de cargo de la empresa receptora de la inversión y al que afecte las utilidades que se le atribuyan y/o los dividendos que se distribuyan en su favor, no se verá afectado con una tasa mayor que aquella considerada en el convenio correspondiente, de manera tal que si el impuesto a la renta de cargo de la empresa aumentara, se reducirá la tasa que afecte al inversionista extranjero en la parte necesaria para permitir que la utilidad de la empresa que finalmente sea de libre disposición para él, sea por lo menos igual a la garantizada.

En lo que respecta a la estabilidad tributaria de la empresa receptora de la inversión, el régimen de estabilidad tributaria que se otorga a las empresas al amparo de lo dispuesto en el artículo $40^{\circ}$ del Decreto Legislativo $\mathrm{N}^{\circ} 757$, implica según dicha norma que en caso de que el Impuesto a la Renta empresarial fuera modificado durante la vigencia del convenio de estabilidad, dichas modificaciones no afectarán a las empresas receptoras de la inversión cuya estabilidad tributaria se encuentre amparada en el convenio correspondiente, ya sea que aumenten o disminuya la tasa, o que se modifique 
la materia imponible ampliándose o reduciéndose, o por cualquier otra causa de efectos equivalentes.

\subsubsection{De las normas tributarias del TUO de la Ley Orgánica de Hidrocarburos.}

En el sector de hidrocarburos, el TUO de la Ley Orgánica de Hidrocarburos, es bastante precisa en su Artículo $48^{\circ}$ al precisar que, para efectos del impuesto a la renta, los contratistas se deberán regir en base al régimen aplicable vigente al momento de la firma de contrato. Es decir, tendrán la estabilidad tipo foto. En caso los contratistas constituyan una sucursal en el país, el impuesto a la renta solo recaerá sobre sus rentas de fuente peruana.

La parte más importante del TUO de la Ley Orgánica de Hidrocarburos - Decreto Supremo $N^{\circ}$ 042-2005-EM es el artículo 50 que regula el cálculo del Impuesto a la Renta que establece:

"Los Contratistas que realicen actividades de exploración y explotación o explotación de Hidrocarburos en más de un área de Contrato y que además desarrollen otras actividades relacionadas con petróleo, gas natural y condensados y actividades energéticas conexas a las de Hidrocarburos, determinarán los resultados de cada ejercicio en forma independiente por cada área de Contrato y por cada actividad para los efectos del cálculo del Impuesto a la Renta.

Si en uno o más de los Contratos o actividades se generasen pérdidas arrastrables, éstas deberán ser compensadas con la utilidad generada por otro $u$ otros Contratos o actividades, a opción del Contratista.

Las inversiones realizadas en un área de Contrato en la que no se hubiera llegado a la etapa de extracción comercial, serán acumuladas al mismo tipo de inversiones efectuadas en otra área de Contrato en la que sí se haya llegado a dicha etapa y el total se amortizará mediante el método elegido, conforme a lo previsto en el Artículo 53 de la presente Ley.” (Ley Orgánica de Hidrocarburos Ley 26221 ) 
Por su parte, el Reglamento de la Garantía de Estabilidad Tributaria y de las Normas Tributarias de la Ley Orgánica de Hidrocarburos - Decreto Supremo No 32-95EF, regula como se compensarán las perdidas en su Artículo $8^{\circ}$ y señala:

“En los casos que el Contratista tenga más de un Contrato, podrá compensar las pérdidas tributarias que se generen en uno o más Contratos con las utilidades provenientes de otros Contratos o de Actividades Relacionadas. Asimismo, las pérdidas tributarias provenientes de Actividades Relacionadas podrán ser compensadas con las utilidades de uno o más Contratos.

Se podrá optar por atribuir las pérdidas tributarias a uno o más de los Contratos o Actividades Relacionadas, que hayan generado las utilidades, siempre que se agoten dichas pérdidas, o que se compensen hasta el límite de las utilidades.

El Contratista que tenga pérdidas tributarias en uno o más contratos o Actividades Relacionadas no las podrá compensar con utilidades generadas por las Otras Actividades. Asimismo, en ningún caso las pérdidas tributarias generadas por las Otras Actividades podrán ser compensadas con las utilidades que provengan de los Contratos o de las Actividades Relacionadas."

En ese sentido puede advertirse qué en el sector de hidrocarburos, a pesar de tener una normatividad rigurosa, tiene reglas que permiten que se puedan compensar las pérdidas a otros contratos que, si tengan utilidades, de modo que resulte una tributación más justa.

3.2.3. De nuestra opinión respecto de lo que podría aportar los Convenios de los Decretos Legislativos 662 y 757 y el TUO de la Ley Orgánica de Hidrocarburos al sector minero.

La estabilidad que tienen los Decretos Legislativos 662 y 757, si bien alcanzan a la empresa receptora de la inversión, solo alcanzan al Impuesto a la Renta; más no a los demás impuestos, a diferencia del sector minero, en el que si está prevista la estabilidad tributaria para los demás impuestos, conforme lo reconoce el Artículo $80^{\circ}$ literal a) del TUO de la Ley General de Minería. En ese sentido, es mucho más rica la estabilidad sectorial minera. 
Ahora, respecto a si es pertinente otorgarle estabilidad tributaria a toda la empresa, en el sector minero, no estaría de acuerdo, ya que, en primer lugar, no se cumpliría el fin promocional sectorial, que es incentivar la actividad minera, dado a que las empresas pueden tener muchos giros de negocio, salvo que sea regulada desde su constitución, como ocurre en el sector financiero, para que todas las actividades sean directamente relacionadas al sector minero, sin embargo, esta garantía de estabilidad, considero que debe tener un plazo limitado, ya que lo que se busca es traer nuevas inversiones.

En cuanto al aporte que puede realizar el sector hidrocarburos al sector minero, este tiene la ventaja que la estabilidad es determinada por el contrato conforme lectura del Artículo $48^{\circ}$ del TUO de la Ley Orgánica de Hidrocarburos, siendo libres de realizar las inversiones adicionales que requiere su actividad, las cuales quedarían igualmente estabilizadas. Quisiéramos recomendar que este sería un régimen idóneo, para el sector minero, sin embargo, este sector es muy sensible, ya que hay una mayor exposición en el manejo de los recursos naturales, por ende, si hay inversiones adicionales, consideramos que estás deben de tener su propio procedimiento para su ampliación frente a la Dirección General de Minería, tal como ocurre cuando se presentan los programas de inversión para efectos que sean aprobados. La Corte Suprema ya hizo su interpretación Constitucional en la Casación № 5212-2016-LIMA y en ella expresó, respecto al Caso Cerro Verde, en el considerando 37, que el diseño contractual está hecho para que "el Estado se halle en posición adecuada de supervisar y fiscalizar cuales son los bienes, servicios y derechos que tendrá que aplicar los beneficios estabilizados a la titular de la actividad minera."

En ese sentido, cualquier modificación legislativa debe sopesar la responsabilidad estatal conforme al análisis constitucional realizado en el capítulo primero de esta tesis, así como de la promoción a la inversión.

Finalmente, en lo que respecta a una norma que aclare la determinación al impuesto a la renta cuando existan convenios de estabilidad mineros, esta debe de realizarse, no solo por el principio de reserva de ley previsto en el Artículo $74^{\circ}$ de la Constitución, sino para efectos de brindar la estabilidad tributaria que es reclamada por las inversiones en el sector. 


\subsection{Del Proyecto de Ley $\mathrm{N}^{\circ} 3664 / 2018$-PE para enmendar los problemas de los Convenios de estabilidad mineros.}

A efectos de solucionar todos los problemas generados por la Ley 30230 y 30296, vino a tallar el proyecto de ley $\mathrm{N}^{\circ} 3664 / 2018$-PE presentado el 26 de noviembre del 2018, y para ello se pretende modificar el Artículo $72^{\circ}, 80^{\circ}, 83-\mathrm{B}, 84^{\circ}$ y $85^{\circ}$ del TUO de la Ley General de Minería.

El dictamen del proyecto de ley $\mathrm{N}^{\circ} 3664 / 2018$-PE fue aprobado el 10 de abril del 2019, sin embargo, hasta la fecha de la presente tesis, todavía no ha sido aprobado en el pleno ni promulgado como Ley.

Este proyecto considera la información remitida por el Ministerio de Energía y Minas sobre los contratos vigentes, los cuales son los siguientes:

\begin{tabular}{|c|c|c|c|c|c|c|c|c|}
\hline \multicolumn{9}{|c|}{ Contratos de estabilidad tributaria } \\
\hline & \multirow{3}{*}{ Empresas } & \multirow{3}{*}{ Proyecto } & \multirow{3}{*}{$\begin{array}{l}\text { Fecha de } \\
\text { suscripción }\end{array}$} & \multirow{3}{*}{$\begin{array}{l}\text { Inversión } \\
\text { US\$ }\end{array}$} & \multicolumn{3}{|c|}{ Estabilidad } & \multirow{3}{*}{ tuación } \\
\hline & & & & & & \multicolumn{2}{|c|}{ Periodo } & \\
\hline & & & & & Años & Inicio & Fin & \\
\hline 1 & $\begin{array}{l}\text { Compañía } \\
\text { Minera } \\
\text { Milpo } \\
\text { S.A.A. }\end{array}$ & $\begin{array}{l}\text { Proyecto } \\
\text { Cerro } \\
\text { Lindo }\end{array}$ & 26.02.2002 & $63 ’ 401,000$ & 15 & $1 / 01 / 2007$ & $\begin{array}{l}31 / 12 / 2 \\
021\end{array}$ & $\begin{array}{l}\text { Contrato } \\
\text { de } \\
\text { estabilidad } \\
\text { tributaria } \\
\text { vigente - } \\
\text { C.E.T }\end{array}$ \\
\hline 2 & $\begin{array}{l}\text { Minera } \\
\text { Barrick } \\
\text { Misquichil } \\
\text { ca S.A. }\end{array}$ & $\begin{array}{l}\text { Proyecto } \\
\text { Alto } \\
\text { Chicama }\end{array}$ & 29.12.2004 & $\begin{array}{l}261^{\prime} 834,000 \\
.0\end{array}$ & 15 & 01/01/2006 & $\begin{array}{l}31 / 12 / 2 \\
020\end{array}$ & $\begin{array}{l}\text { Contrato } \\
\text { de } \\
\text { estabilidad } \\
\text { tributaria } \\
\text { vigente - } \\
\text { C.E.T }\end{array}$ \\
\hline 3 & $\begin{array}{l}\text { Minera } \\
\text { Chinalco } \\
\text { S.A. }\end{array}$ & $\begin{array}{l}\text { Toromoc } \\
\text { ho }\end{array}$ & 09.03.2009 & $\begin{array}{l}4,383^{\prime} 580,4 \\
82\end{array}$ & 15 & - & - & $\begin{array}{l}\text { Tiene } \\
\text { C.E.T. } \\
\text { pero no } \\
\text { tiene fecha }\end{array}$ \\
\hline
\end{tabular}




\begin{tabular}{|c|c|c|c|c|c|c|c|c|}
\hline & & & & & & & & $\begin{array}{l}\text { de inicio de } \\
\text { estabilidad } \\
\text { por tener } \\
\text { ampliación } \\
\text { en marcha } \\
\text { ( } 2021 \\
\text { aprox.) }\end{array}$ \\
\hline 4 & $\begin{array}{l}\text { Compañía } \\
\text { Minera } \\
\text { Antapacay } \\
\text { S.A. }\end{array}$ & $\begin{array}{l}\text { Antapacc } \\
\text { ay }\end{array}$ & 17.11.2011 & $853^{\prime} 912,000$ & 15 & 01/01/2014 & $\begin{array}{l}31 / 12 / 2 \\
028\end{array}$ & $\begin{array}{l}\text { Contrato } \\
\text { de } \\
\text { estabilidad } \\
\text { tributaria } \\
\text { vigente - } \\
\text { C.E.T }\end{array}$ \\
\hline 5 & $\begin{array}{l}\text { Minera } \\
\text { Las } \\
\text { Bambas } \\
\text { S.A, }\end{array}$ & $\begin{array}{l}\text { Las } \\
\text { Bambas }\end{array}$ & 20.07 .2011 & $\begin{array}{l}5,895^{\prime}, 000,0 \\
00\end{array}$ & 15 & 01/01/2016 & $\begin{array}{l}30 / 12 / 2 \\
019\end{array}$ & $\begin{array}{l}\text { Contrato } \\
\text { de } \\
\text { estabilidad } \\
\text { tributaria } \\
\text { vigente - } \\
\text { C.E.T }\end{array}$ \\
\hline 6 & $\begin{array}{l}\text { Sociedad } \\
\text { Minera } \\
\text { Cerro } \\
\text { Verde } \\
\text { S.A.A. }\end{array}$ & $\begin{array}{l}\text { Expansió } \\
\text { n UP } \\
\text { Cerro } \\
\text { Verde }\end{array}$ & 17.07.2012 & $\begin{array}{l}5,287^{\prime} 477,0 \\
00\end{array}$ & 15 & 01/01/2014 & $\begin{array}{l}31 / 12 / 2 \\
028\end{array}$ & $\begin{array}{l}\text { Contrato } \\
\text { de } \\
\text { estabilidad } \\
\text { tributaria } \\
\text { vigente - } \\
\text { C.E.T }\end{array}$ \\
\hline 7 & $\begin{array}{l}\text { Hudbay } \\
\text { Perú } \\
\text { S.A.A. }\end{array}$ & $\begin{array}{l}\text { Constanc } \\
\text { ia }\end{array}$ & 27.12.2013 & $\begin{array}{l}1,756^{\prime}, 715,8 \\
41\end{array}$ & 15 & 01/01/2016 & $\begin{array}{l}31 / 12 / 2 \\
030\end{array}$ & $\begin{array}{l}\text { Contrato } \\
\text { de } \\
\text { estabilidad } \\
\text { tributaria } \\
\text { vigente - } \\
\text { C.E.T }\end{array}$ \\
\hline
\end{tabular}

Este proyecto, empieza modificando el último párrafo del Artículo $72^{\circ}$ y el inciso a) del Artículo $80^{\circ}$ del TUO de la Ley General de Minería, para que quede expresamente previsto en el TUO de la Ley General de Minería que para la estabilidad vigente para efectos de la estabilidad es la norma vigente a la fecha de suscripción del contrato. El 
legislador consideró pertinente realizar esta modificación, ya que la Ley 30230 al modificar el Artículo $85^{\circ}$ del TUO cambió la fecha de la estabilidad a la fecha de aprobación del estudio de factibilidad para los regímenes de 12 y 15 años por lo que el proyecto de ley mencionado pretende enmendar esta situación. Respecto a este cambio, nuestra opinión a favor de dicha modificación, ya que ello estaría en el mismo sentido que la Ley 27343 que regula la estabilidad de las leyes sectoriales.

Asimismo, se propuso modificar el inciso a) del Artículo $80^{\circ}$ del TUO de la Ley General de Minería, a efectos de que se entienda que la estabilidad tributaria sea únicamente impositiva, a fin de seguir el mismo tratamiento previsto en la Ley 27343, que regula la estabilidad de las leyes sectoriales.

Otra modificación propuesta fue para el Artículo 83-B del TUO de la Ley General de Minería que propone retirar la palabra "exclusivamente" en el tercer párrafo de dicho artículo, porque dicho término indicaría que solo están estabilizadas las inversiones del proyecto más las adicionales posteriores a la firma del contrato; ello para poder concordarlo con el Artículo 83-A y comprender las inversiones contenidas en el programa de inversión, las adicionales a este programa y aquellas inversiones que se hubieren ejecutado con anterioridad a la fecha de presentación de la solicitud de suscripción del convenio de estabilidad.

Nuestra opinión, respecto a lo mencionado por el legislador, consideramos con el debido respeto que no es correcta esa justificación, ya que recién es en dicho proyecto, en que se añade un quinto párrafo nuevo en el Artículo 83-B, con la finalidad de incluir dentro de la misma a las inversiones de desarrollo ejecutadas con anterioridad a la presentación de la solicitud de suscripción de convenio de estabilidad. Nuestra opinión, es que debería de mantenerse el término referido a que "el beneficio contractual recae exclusivamente en las actividades de la empresa minera a favor de la cual se efectúa la inversión", toda vez que la estabilidad del sector minero estabiliza únicamente la inversión que se ejecute para realizar la actividad minera estabilizada; y considerando que en el nuevo quinto párrafo del 83-B que se añade en el proyecto de ley, se señala con claridad lo pretendido por el legislador en forma expresa, no oponiéndonos a dicho cambio legislativo.

En cuanto a la nueva redacción del Artículo $84^{\circ}$ del TUO de la Ley General de Minería, el proyecto de ley precisa con claridad que en los proyectos de 12 y 15 años se 
otorgan los beneficios del Artículo $80^{\circ}$ del TUO, lo cual nos parece un acierto, ya que el legislador, al incorporar los Artículos $83^{\circ}-\mathrm{A}$ y $83-\mathrm{B}^{\circ}$ en la Ley 30230 , no le puso los beneficios contractuales del Artículo $80^{\circ}$ a la estabilidad de 12 años. De la misma manera, se corrige lo concerniente a la depreciación acelerada para los activos fijos, la cual ya le es aplicable a los Convenios de 12 y 15 años.

Por otro lado, respecto a la modificación que se hace en el segundo párrafo del Artículo $84^{\circ}$ del TUO de la Ley General de Minería, se reincorpora la contabilidad de moneda extranjera a la estabilidad de 15 años, siendo aplicable de esta manera para los convenios de 12 y 15 años; hecho que nos parece una mejor solución.

Respecto a la modificación de los convenios del Artículo $85^{\circ}$ del TUO de la Ley General de Minería, se mantiene la misma redacción, retirándole que la fecha de aprobación ficta será la que aplique para efectos de fijar la fecha de la estabilidad tributaria. Esta corrección nos parece que era necesaria, ya que volvía a traer en discusión cuando era la fecha que debía de tomarse en cuenta para fijar la estabilidad, aspecto que ya había resuelto la Ley 27343, al precisar que era la fecha del contrato.

\section{CAPÍTULO IV: CONCLUSIONES}

A continuación, desarrollamos las conclusiones a las que hemos llegado por los problemas y antecedentes descritos en los capítulos anteriores sobre la inversión del sector minero en los convenios de estabilidad y regímenes tributarios, ya que tenemos problemas graves y no solo de forma o estructura sino de fondo.

4.1. En lo que respecta a las inversiones adicionales ejecutadas con posterioridad al programa de inversiones, consideramos que el monto de US\$25’000,000.00 previsto en el Artículo 83-B del TUO de la Ley General de Minería, si bien es una suma modesta para el sector minero, es bastante razonable dado a que no se les va a otorgar una extensión al plazo original del convenio y estas inversiones 
adicionales deben ser ejecutadas dentro del periodo de vigencia del convenio original.

4.2. Por otro lado, consideramos que las inversiones adicionales estás deben aplicar tanto para la estabilidad de 10 y 15 años, manteniéndose el requisito de que estén ubicadas donde se encuentre el proyecto de inversión original y deben de tener su propio programa de inversión, el cual debe ser aprobado por la Dirección General de Minería, debiendo de suscribirse la adenda correspondiente, en ese sentido, consideramos que esta debe ser una redacción más adecuada que la realizada en la modificación de la Ley 30296 al Artículo 83-B del TUO de la Ley General de Minería.

4.3. Consideramos que siguiendo la lógica del proyecto de Ley $\mathrm{N}^{\circ} 3664 / 2018$-PE, puede admitirse la inclusión de las inversiones de desarrollo que se hubieran ejecutado con anterioridad a la presentación de la solicitud de convenio, siempre que sean incluidas en el estudio de factibilidad, y que están plenamente justificadas para efectos de facilitar el desarrollo del proyecto. Esto se haría con la finalidad que alcanzar más rápido la etapa productiva.

4.4. Nos parece correcto que la Ley 30230 y 30296 haya extendido y agregado más requisitos como los de la producción y montos mínimos de inversión para acceder a los Convenios de Estabilidad, ya que estos deben ser actualizados acorde a lo que realmente ocurre en el sector, somos de la impresión, que no ha habido ningún fundamento técnico para realizar dichos cambios, siendo estas disposiciones improvisadas, ya que no se ha encontrado ningún detalle técnico que sea relevante, en los dictámenes de las comisiones del Congreso de la República, ni en el diario de debates.

4.5. En este punto consideramos dejar constancia, que no existe proporcionalidad en las inversiones de 12 y 15 años, ya que la de 12 años exige una capacidad inicial o en caso de ampliaciones para llegar a las 5,000 TM/día, mientras que en las inversiones de 15 años se exige una capacidad inicial de 15,000 TM/día o de ampliaciones para llegar a una capacidad de 20,000 TM/día. Igualmente se exige para las convenios US\$ 100’000,000.00 en los convenios de 12 años como inversión inicial y en las empresas que ya realicen actividades mineras se exige US\$ 250’000,000.00; mientras que en los convenios de estabilidad de 15 años se exige US\$ 500’000,000.00. En otras palabras, se exige producir tres veces más e invertir 
cinco veces más dinero que los convenios de 12 años, para suscribir convenios de 15 años, y su único beneficio contractual serían tres años adicionales de estabilidad, hecho que consideramos que no es coherente con la finalidad de incentivar la inversión.

4.6. Nos parece adecuado que se haya corregido los Artículos $82^{\circ}$ y $83-\mathrm{B}$ en lo referente a los requisitos para acceder a la estabilidad en más de una concesión o en una o más Unidades Económico - Administrativas (UEA). Lo que si no nos parece adecuado es que se haya modificado el concepto de UEA en el Artículo 82 ${ }^{\circ}$, el cual aplica exclusivamente para los convenios de estabilidad, en lugar de modificarse el Artículo $44^{\circ}$ del TUO de la Ley General de Minería que define la UEA, que sería lo más lógico.

4.7. Consideramos que se debe modificar el Artículo $84^{\circ}$ del TUO de la Ley General de Minería a efectos de incluir el derecho a tener contabilidad en moneda extranjera en los Convenios de 10 y de 15 años.

4.8. Tal como hemos señalado en el apartado correspondiente, a raíz de las modificaciones de la Ley 30230, a la estabilidad de 12 años no se le otorgó los beneficios del Artículo $80^{\circ}$, ni se le otorgó la facultad de ampliar la tasa de depreciación de sus activos conforme se puede apreciar en el artículo $84^{\circ}$ del TUO de la Ley General de Minería, hecho que evidencia que ha habido mucha improvisación en la Ley 30230 y en la Ley 30296.

4.9. Otro problema generado por la Ley 30230 fue que al modificar el Artículo $85^{\circ}$ del TUO de la Ley General de Minería consideró que la fecha de aprobación del estudio de factibilidad será la que sirva para efectos de fijar la fecha de la estabilidad para los convenios de 12 y 15 años; dejando de esta manera de lado lo previsto en la Ley 27343, que refiere que la fecha de estabilidad fijada en atención a la fecha de suscripción del contrato.

4.10. Una propuesta interesante hecha por el proyecto de Ley $\mathrm{N}^{\circ} 3664 / 2018$-PE, es modificar el literal a) del Artículo $80^{\circ}$ del TUO de la Ley General de Minería para que se redefina como estabilidad tributaria, como estabilidad impositiva, de esa manera el ordenamiento sería coherente con la Ley 27343.

4.11. Por otro lado, consideramos que dada la situación presentada en la RTF $N^{\circ} 20290$ 1-2011, respecto a la interpretación del Artículo $22^{\circ}$ del Reglamento de la Ley General de Minería - Decreto Supremo Nº24-93-EM, y pese a existir el informe 
de SUNAT $\mathrm{N}^{\circ}$ 084-2012-SUNAT/4B0000, todo aspecto referente a la determinación del impuesto a la renta y el arrastre de perdidas cuando se tiene actividades que tienen diferentes tratamientos normativos con motivo de los convenios de estabilidad suscritos, estos deben estar contemplados en el TUO de la Ley General de Minería, respetando el principio de legalidad reconocido en el Artículo $74^{\circ}$ de la Constitución del Estado.

4.12. Finalmente, consideramos que la estabilidad tributaria debería de considerar la estabilidad en la interpretación, en respeto a la confianza legitima, tal como ha sido analizado en puntos anteriores.

4.13. Por lo antes mencionando, las empresas no tienen la confianza para celebrar un convenio de estabilidad, en razón a que el ordenamiento vigente no solo es confuso, sino que exige requisitos de producción e inversión altos. Es por lo antes mencionado que el último convenio suscrito con el Estado fue suscrito el 27 de diciembre del 2013, con el proyecto Constancia.

4.14. En conclusión, podemos señalar que los convenios de estabilidad no están cumpliendo con su finalidad, la cual es incentivar la inversión. En el siguiente punto, desarrollaremos las recomendaciones que podemos brindar desde nuestra perspectiva, para que los convenios de estabilidad sirvan como un vehículo de promoción de inversión.

\section{CAPÍTULO V: RECOMENDACIONES}

A continuación, plantearemos las recomendaciones que debería realizar el Estado Peruano para evitar este tipo de conflictos y así estimular la inversión:

5.1. En lo que respecta a las inversiones adicionales, nuestra recomendación sería que estás sean aplicables para los convenios de 10 y 15 años, además debemos de definir con claridad lo que es una inversión adicional, y aclarar que tal como el programa de inversiones original, estas inversiones adicionales también deben aprobadas por la Dirección General de Minería, debiendo suscribirse la adenda correspondiente con el Estado. Ensayando una definición, podría ser en el siguiente modo: 
"Se entiende como inversiones adicionales, a todas aquellas inversiones que se ejecuten con posterioridad al programa de inversiones contenido en el convenio original, y que estén destinadas a incrementar la productividad, en la explotación, procesamiento y transporte de mineral dentro de la concesión o concesiones mineras o una o más unidades económicas administrativas donde se desarrolla el proyecto de inversión materia del contrato suscrito con el Estado. Su inversión será no menor a US\$ 25’000,000.00 y su programa de inversiones será aprobado por la Dirección General de Minería, debiendo de suscribirse la adenda al contrato de estabilidad que corresponda a efectos de que sea integrada al convenio original."

Si bien este cambio puede verse a primera vista conservador, ello es necesario, a fin de mantener una unidad en materia de regulación, tanto de las inversiones primigenias como de las adicionales.

5.2. En nuestras recomendaciones, también recogemos el planteamiento expresado en el proyecto de Ley $\mathrm{N}^{\circ} 3664 / 2018-\mathrm{PE}$ respecto a las inversiones anteriores a la presentación de la solicitud de convenio, siempre que sean incluidas en el estudio de factibilidad y que están plenamente justificadas para efectos de facilitar el desarrollo del proyecto y que este llegue a la etapa productiva. Este pedido es bastante adecuado, ya que su inclusión va a ser evaluada por la Dirección General de Minería y de todas maneras van a ser incluidas en el estudio de factibilidad que dará origen al Convenio de estabilidad.

5.3. Como recomendación eliminaríamos la estabilidad de 12 años, quedándonos únicamente con la estabilidad de 10 años y la de 15 años. Respecto de los requisitos de la estabilidad de 10 años, no haríamos cambio alguno. Y respecto a la estabilidad de 15 años, bajaría la capacidad inicial de producción o de ampliación, para exigir únicamente 5,000 TM/día, tal como era originalmente. Asimismo, bajaríamos en la estabilidad de 15 años, el monto mínimo de inversión al convenio de estabilidad a la suma de US\$250’000,000.00, ya sea si inician la actividad o ya estén realizando actividades mineras. Si bien en seis de los siete convenios de estabilidad vigentes y que han sido reproducidos en el Dictamen del proyecto de ley 3664/2018-PE, se ha invertido sumas mayores a la propuesta, debe tenerse en consideración que la finalidad del Convenio de estabilidad es la promoción de la inversión, y si 
colocamos las barreras de acceso en forma que estás sean más accesibles, hay posibilidad de que existan mayores inversiones en el sector.

5.4. En lo que respecta a la definición de Unidad Económica Administrativa prevista en el Artículo $82^{\circ}$ del TUO de la Ley General de Minería, lo cambiaríamos de lugar para que este sea consignado en el Artículo $44^{\circ}$ del TUO de la Ley General de Minería, a fin de que sea una definición única que aplique a todo el sector minero independientemente de si tienen convenios de estabilidad o no.

5.5. Recomendamos modificar el artículo $84^{\circ}$ del TUO de la Ley General de Minería, a efecto de que el derecho a llevar contabilidad en moneda extranjera sea aplicado a los Convenios de 10 y 15 años, ya que como hemos expresado en líneas atrás, es la moneda funcional en el sector minero, ya que las ventas de mineral y muchas de sus adquisiciones se hacen en dólares americanos.

5.6. Respecto a la falta de los beneficios del Artículo $80^{\circ}$ y falta de la facultad de ampliar la depreciación a los activos fijos en la estabilidad de 12 años en el Artículo $85^{\circ}$ del TUO de la Ley General de Minería, no le haríamos cambio alguno, ya que hemos propuesto eliminar este régimen.

5.7. Respecto al Artículo $85^{\circ}$ del TUO de la Ley General de Minería eliminaría del primer párrafo la parte referida que en la aprobación ficta, se considerará como fecha de la estabilidad del régimen tributario el último día; ello, en razón a que la Ley 27343 menciona que la estabilidad considera los impuestos vigentes al momento de suscripción del contrato.

5.8. Asimismo, tomando en cuenta la sugerencia del proyecto de ley $\mathrm{N}^{\circ} 3664 / 2018-\mathrm{PE}$, modificaríamos el literal a) del Artículo $80^{\circ}$ del TUO de la Ley General de Minería para que se redefina como estabilidad tributaria, como estabilidad impositiva, de esa manera el ordenamiento sería coherente con la Ley 27343.

5.9. Por otro lado, modificaríamos el último párrafo del Artículo $72^{\circ}$ y el literal a) del Artículo $80^{\circ}$ del TUO de la Ley General de Minería, a efectos de hacer coincidir los beneficios de la estabilidad jurídica y tributaria al momento de suscripción de los contratos, ello sería aplicable a la estabilidad de 10 y 15 años.

5.10. Respecto a la determinación del impuesto a la renta, cuando existan inversiones no estabilizadas e inversiones con diferentes estabilidades, insertaría en norma con carácter de ley una norma similar al Artículo $22^{\circ}$ del Reglamento - Decreto 
Supremo 024-93-EM con el Artículo 50 del TUO de la Ley de Hidrocarburos, con la siguiente redacción:

"Los titulares de la actividad minera con convenios de estabilidad, determinarán los resultados de cada ejercicio en forma independiente por cada convenio y por las inversiones no estabilizadas.

Si en uno o más de los convenios o actividades se generasen pérdidas arrastrables, estás deberán ser compensadas con la utilidad generada por otro u otros convenios o inversiones no estabilizadas, a libre elección del titular."

En principio deberíamos determinar el cambio de los plazos establecidos en los convenios de estabilidad (10, 12 y 15 años), a efectos de que no exista mayor confusión. Como vimos en los capítulos anteriores, la incorporación de la estabilidad de 12 años generó tal desorden legislativo que ha impedido que se suscriba nuevos convenios de estabilidad en el sector. En ese sentido debería de eliminarse la estabilidad de 12 años, para considerar únicamente la estabilidad de 10 y 15 años.

En caso de los convenios de 12 y 15 años, debería existir solo el convenio de 15 años, de esa manera no habría confusiones sobre los beneficios de la estabilidad es decir la contabilidad en moneda extranjera es muy importante, porque se llegó a la conclusión que el negocio del sector minero es en dólares y la depreciación acelerada. Seguiría con la misma inversión mínima \$500,000,000.00 dólares, ya que es importante asegurar un monto de inversión para el país.

5.11. Para concluir, proponemos modificar el literal a) del artículo $80^{\circ}$ del TUO de la Ley General de Minería, a efectos de que se incluya dentro de la estabilidad tributaria la interpretación de las normas tributarias estabilizadas que haya sido emitida por informes de la Administración Tributaria o resoluciones del Tribunal Fiscal con carácter de observancia obligatoria. Esto tiene la finalidad, de preservar la confianza legitima que tiene el inversionista al suscribir los Convenios de Estabilidad, de que no habrá modificaciones en la interpretación de las normas estabilizadas, que puedan afectar el derecho a recibir los legítimos dividendos provenientes de su inversión. 


\section{Bibliografía}

¿Cómo se logró estabilizar la economía peruana en la década de los 90? . ( 2017). Obtenido de Diario Gestion: https://gestion.pe/economia/logro-estabilizareconomia-peruana-decada-90-147090

¿Por qué el Perú sigue siendo atractivo para las inversionistas? (2018). Obtenido de Diario El Comercio: https://elcomercio.pe/especial/zona-ejecutiva/actualidad/que-perusigue-siendo-atractivo-inversionistas-noticia-1993190)

Actualidad empresarial. (2016). Actualidad Empresarial $N^{\circ} 363$ - Segunda Quincena Noviembre del 2016.

Banco Central de Reserva del Perú. (22 de agosto de 2019). PBI por Sectores. Obtenido de BCRPData: https://estadisticas.bcrp.gob.pe/estadisticas/series/mensuales/pbipor-sectores

Barletta, F., Pereira, M., Robert, V., \& Yoguel, G. (2013). Argentina: dinámica reciente del sector de software y servicios informáticos. Revista de la CEPAL(110), 137$155 . \quad$ Obtenido de http://www.cepal.org/publicaciones/xml/1/50511/RVE110Yoqueletal.pdf

Castagnino Abásalo, R. (s.f.). Formas Contractuales en la Industria de Hidrocarburos Peruana. Obtenido de Derecho y Sociedad: http://revistas.pucp.edu.pe/index.php/derechoysociedad/article/download/13263/ 13880

Choy, M., \& Chang, G. (2014). Medidas macroprudenciales aplicadas en el Perú. Lima: Banco Central de Reserva del Perú. Obtenido de http://www.bcrp.gob.pe/docs/Publicaciones/Documentos-deTrabajo/2014/documento-de-trabajo-07-2014.pdf

Congreso de la República. (2019). Expediente virtual parlamentario. Obtenido de $\begin{array}{llll}\text { Congreso de la } & \text { República: }\end{array}$ http://www2.congreso.gob.pe/Sicr/TraDocEstProc/Contdoc02_2011_2.nsf/d995 75da99ebfbe305256f2e006d1cf0/0520187b7c2dc75f05257d9c007f88a6/\$FILE/ 04007DC09MAY261114.-.pdf 
Congreso

del

Peru.

(s.f.).

Obtenido

de

http://www4.congreso.gob.pe/ntley/Imagenes/Constitu/Cons1993.pdf

Consejo Normativo de Contabilidad. (2018). NIC 21. Obtenido de Normas Internacionales de Contabilidad Oficializadas: https://www.mef.gob.pe/contenidos/conta_publ/con_nor_co/vigentes/nic/RedBV 2018_IAS21_GVT.pdf

Constitución Política del Perú. (1993). Sistema Peruano de Información Jurídica. Obtenido de

SPIJ: http://spijlibre.minjus.gob.pe/CLP/contenidos.dll/CLPlegcargen/coleccion00000 .htm/tomo00249.htm/sumilla00250.htm?f=templates $\$$ fn=documentframe.htm\$3.0\#JD_Constitucion_1993

Decreto Legislativo 674. (s.f.). Promulgan la Ley de Promoción de la Inversión Privada de las Empresas del Estado. Obtenido de Sistema Peruano de Información Jurídica:

http://spijlibre.minjus.gob.pe/CLP/contenidos.dll/CLPlegcargen/coleccion00000 .htm/tomo00447.htm/a\%C3\%B1 o66941.htm/mes69212.htm/dia69492.htm/secto r69493.htm/sumilla69494.htm

Decreto Supremo N $^{\circ}$ 014-92-EM. (s.f.). Sistema Peruano de Información Jurídica. Obtenido de http://spijlibre.minjus.gob.pe/CLP/contenidos.dll/CLPlegcargen/coleccion00000 .htm/tomo00447.htm/a\%C3\%B1o70542.htm/mes72368.htm/dia72397.htm/secto r72398.htm/sumilla72399.htm

Diario El Comercio. (2017). Obtenido de Diario El Comercio: https://elcomercio.pe/economia/peru/son-9-mayores-productores-gas-naturalperu-209387?foto $=7$

Diario Gestión. (2004). Riesgo país de Perú alcanza nuevo nivel mínimo histórico. Suplemento de Negocios y Finanzas del Diario Gestión, 9.

El Comercio. (25 de abril de 2017). Cae la Recaudación Tributaria. ¿Cómo levantarla? Obtenido de http://elcomercio.pe/economia/peru/cae-recaudacion-tributariacomo-levantarla-noticia-1986563 
El economista. (21 de 02 de 2017). ¿Cuánto aportó la minería al PBI peruano el 2016? Obtenido de El economista: http://www.eleconomistaamerica.pe/economia-eAmperu/noticias/8171415/02/17/Cuanto-aporto-la-mineria-al-PBI-peruano-el2016.html

Energia Geotermica, Osinergmin. (s.f.). Obtenido de OSINERGMIN: http://www.osinergmin.gob.pe/empresas/energias-renovables/energiageotermica

Ernst \& Young Global Limited. (s.f.). Obtenido de Ernst \& Young Global Limited: https://www.ey.com/pe/es/newsroom/news-releases/news-ey-ley-organicahidrocarburos

García Nieto, J. P. (2013). Consturye tu Web comercial: de la idea al negocio. Madrid: RA-MA.

Gestión. (02 de mayo de 2011). Cuatro mineras concentran el 65\% del Impuesto a la Renta. Obtenido de Diario Gestión: http://gestion.pe/noticia/751325/cuatromineras-concentran-65-impuesto-renta

Gestión. (07 de 2012). Economía Mundial 2012: ¿comenzó la desaceleración? Obtenido de Economía para todos: http://blogs.gestion.pe/economiaparatodos/2012/07/economia-mundial-2012comenzo.html

Gestión. (03 de abril de 2014). Recaudación por nuevo marco tributario minero sumó S/. 1,664 millones el 2013. Obtenido de Gestión: http://gestion.pe/economia/recaudacion-nuevo-marco-tributario-minero-sumo-s1664-millones-2013-2093610

Gestión. (s.f.). Mayor produccion de cobre y zinc impulsarian PBI minero. Obtenido de Gestión: $\quad$ http://gestion.pe/economia/mayor-produccion-cobre-y-zincimpulsarian-pbi-minero-alrededor-8-2017-2181496)

Instituto peruano de Economía. (19 de abril de 2018). Aporte de la minería al PBI. Obtenido de Instituto Peruano de Economía: https://www.ipe.org.pe/portal/aporte-de-la-mineria-al-pbi/ 
José Miguel Morales Dasso. (s.f.). Obtenido de Aciertos y debilidades de la Legislacion Minera

Actual: http://revistas.pucp.edu.pe/index.php/derechoadministrativo/article/viewFile/139 $90 / 14612$

La República. (s.f.). La economía del Perú creció 3,9\% el 2016, pero aún es bajo. Obtenido de La República: http://larepublica.pe/impresa/economia/848899-laeconomia-del-peru-crecio-39-el-2016-pero-aun-es-bajo

Las empresas más importantes del Perú: sector del petróleo y del gas. (01 de 04 de 2019).

Obtenido de Rankia: https://www.rankia.pe/blog/analisis-igbvl/2351512empresas-mas-importantes-peru-sector-petroleo-gas

Ley 26821. (26 de Junio de 1997). Sistema Peruano de Información Jurídica. Obtenido de

http://spijlibre.minjus.gob.pe/CLP/contenidos.dll/CLPlegcargen/coleccion00000 .htm/tomo00447.htm/a\%C3\%B1o90915.htm/mes92509.htm/dia92807.htm/secto r92808.htm/sumilla92809.htm

Ley de Promoción del Desarrollo de la Industria del Gas, Ley 28552. (s.f.). Obtenido de Osinerming:

http://gasnatural.osinerg.gob.pe/contenidos/uploads/GFGN/NormasGFGN/NOR MATIVIDAD\%20GENERAL/PROMOCION\%20INDUSTRIA\%20DEL\%20G AS\%20NATURAL/Ley\%2028552.pdf

Ley Orgánica de Hidrocarburos - Ley 26221 . (s.f.). Obtenido de OSINERG: http://www2.osinerg.gob.pe/MarcoLegal/pdf/LEYOH-\%2026221.pdf

Ministerio de Economía y Finanzas. (s.f.). El marco conceptual para la información financiera. Obtenido de Ministerio de Economía y Finanzas: https://www.mef.gob.pe/contenidos/conta_publ/con_nor_co/no_oficializ/ES_G VT_RedBV2016_conceptual.pdf

Ministerio de Energía y Minas. (2017). Cartera Estimada de Proyectos Mineros. Obtenido de Ministerio de Energía y Minas: http://www.minem.gob.pe/minem/archivos/file/Mineria/INVERSION/2017/CA RTERA01_2017.pdf 
Ministerio de Energía y Minas. (s.f.). Contratos de Garantias y Promoción de la Inversión. Obtenido de Ministerio de Energía y Minas: http://www.minem.gob.pe/_detalle.php?idSector=1\&idTitular=188\&idMenu=su b154\&idCateg $=188$

Ministerio de Energía y Minas. (s.f.). Contratos de Garantías y Promoción de la Inversión. Obtenido de Ministerio de Energía y Minas: http://www.minem.gob.pe/_detalle.php?idSector=1\&idTitular=188\&idMenu=su b154\&idCateg $=188$

Ministerio de Justicia. (2019). Ley 30230. Obtenido de Sistema Peruano de Información Jurídica:

http://spijlibre.minjus.gob.pe/CLP/contenidos.dll/CLPlegcargen/coleccion00000 .htm/tomo00448.htm/a\%C3\%B1o410735.htm/mes422530.htm/dia423351.htm/s ector423352.htm/sumilla423355.htm

Ministerio Público. (s.f.). Ministerio Público. Obtenido de https://www.mpfn.gob.pe/escuela/contenido/actividades/docs/692_ponencia_del _07.pdf

Osinerming, Industria del gas natural. (s.f.). Obtenido de OSINERMING: http://www2.osinerg.gob.pe/Pagina\%20Osinergmin/Gas\%20Natural/Contenido/ cult001.html

PAREDES, J. (2018). Obtenido de RUNA YACHACHIY: http://www.alberdi.de/BreaParinas-Paredes.pdf

PETRO PERU SA. (s.f.). Obtenido de PETRO PERU SA: https://www.perupetro.com.pe/wps/portal/corporativo/PerupetroSite/perupetro\% 20s.a./historia/!ut/p/z0/04_Sj9CPykssy0xPLMnMz0vMAfIjo8zi_YxcTTw8TAy 93AN8LQwCTUJcvEKADF8fA_3g1GL9gmxHRQBkwZvu/

Real Academía de la Lengua Española. (s.f.). Diccionario de la Real Academía de la Lengua Española. Obtenido de Diccionario de la Real Academía de la Lengua Española: http://dle.rae.es/?id=SYPEPhR 
Redacción Diario Gestion. (s.f.). Obtenido de DIARIO GESTION: https://gestion.pe/economia/mem-hay-16-proyectos-geotermicos-faseexploracion-ninguno-explotacion-220111

Ritimo. (24 de junio de 2016). Las tendencias de la inversión minera a nivel mundial y el caso de América Latina. Obtenido de Ritimo: http://www.ritimo.org/Lastendencias-de-la-inversion-minera-a-nivel-mundial-y-el-caso-de-America

RTF $\quad \mathrm{N}^{\circ}$ 18397-10-2013. (s.f.). Tribunal Fiscal. Obtenido de http://www.mef.gob.pe/contenidos/tribu_fisc/Tribunal_Fiscal/PDFS/2013/10/20 13_10_18397.pdf

Rumbo Minero. (s.f.). Perú queda segundo en Latinoamerica en ranking mundial de mineria. Obtenido de Rumbo Minero: http://www.rumbominero.com/noticias/mineria/peru-queda-segundo-enlatinoamerica-en-ranking-mundial-de-mineria/

Schreck, Marcial Garcia. (2005).

Sentencia del Tribunal Constitucional $\mathrm{N}^{\circ}$ 01848-2011-AA. (s.f.). Tribunal Constitucional. Obtenido de https://www.tc.gob.pe/jurisprudencia/2011/018482011-AA.html

Sentencia $\mathrm{N}^{\circ}$ 00005-2003-AI. (2003). Tribunal Constitucional. Obtenido de https://www.tc.gob.pe/jurisprudencia/2003/00005-2003-AI.html

Sistema de arrastre de perdidas. (s.f.). Obtenido de Estudio Caballero Bustamante: http://caballerobustamante.com.pe/plantilla/lab/radio_230309_3.pdf)

$\begin{array}{llll}\text { SUNAT. } & \text { (s.f.). } & \text { Estadisticas. } & \text { Sunido }\end{array}$ http://www.sunat.gob.pe/estadisticasestudios/index.html

Taboada Pérez, F. A. (2014). Alcances de los Contratos de estabilidad Tributaria del Sector Minero. Derecho y sociedad 43, 337-344.

TUO de la Ley General de Hidrocaburos - Decreto Supremo Nº 042-2005-EM. (14 de octubre de 2005). Sistema Peruano de Información Jurídica. Obtenido de http://spijlibre.minjus.gob.pe/CLP/contenidos.dll/CLPlegcargen/coleccion00000 .htm/tomo00447.htm/a\%C3\%B1o199710.htm/mes218581.htm/dia219348.htm/s ector219366.htm/sumilla219368.htm 
Wikipedia. (s.f.). Wikipedia. Obtenido de Ring Fencing: https://en.wikipedia.org/wiki/Ringfencing

Wittmann, R. (2006). ¿Hubo una revolución en la lectura a finales del siglo XVIII? En G. Cavallo, \& R. Chartier, Historia de la lectura en el mundo occidental (págs. 435472). México D.F.: Santillana. 